Pontifícia Universidade Católica $_{\text {ata }}$

DO RIO DE JANEIRO

Augusto Moreira de Carvalho Junior

NOVAÇÃO - COMO O MESMO SE TORNA OUTRO?

- Representação e diferença no pensamento de Gilles Deleuze

Dissertação de Mestrado

Dissertação apresentada ao Programa de Pós-graduação em Filosofia da PUC-Rio como requisito parcial para obtenção do grau de Mestre em Filosofia.

Orientador: Prof. Paulo Cesar Duque Estrada

Rio de Janeiro Novembro de 2016 


\section{Pontifícia Universidade Católica $_{\text {ato }}$ \\ DO RIO DE JANEIRO}

Augusto Moreira de Carvalho Junior

\section{NOVAÇÃO - COMO O MESMO SE TORNA OUTRO? \\ - Representação e diferença no pensamento de Gilles Deleuze}

Prof. Paulo Cesar Duque Estrada

Orientador

Departamento de Filosofia - PUC Rio

Dissertação apresentada ao Programa de Pós-graduação em Filosofia da PUC-Rio como requisito parcial para obtenção do grau de Mestre em Filosofia. Aprovada pela Comissão Examinadora abaixo assinada.

Prof. Rodrigo Guimarães Nunes Departamento de Filosofia - PUC Rio

Prof. James Bastos Arêas Instituto de Filosofia e Ciências Humanas - UERJ

Profa. Monah Winograd Coordenadora Setorial do Centro de Teologia e Ciências Humanas - PUC-Rio

Rio de Janeiro. 10 de novembro de 2016 
Todos os direitos reservados. É proibida a reprodução total ou parcial do trabalho sem autorização do autor, do orientador e da universidade.

\section{Augusto Moreira de Carvalho Junior}

O autor graduado em Filosofia pela Faculdade de Filosofia da Universidade do Estado do Rio de Janeiro - UERJ em 2011. Professor DOC 1 da SEEDUC RJ em Teresópolis e Sumidouro. Participa como divulgador do projeto de física de partículas CERN - Masterclass, promovendo palestras sobre a relação física/filosofia.

Ficha Catalográfica

Carvalho Junior, Augusto Moreira De

Novação - como o mesmo se torna outro? - representação e diferença no pensamento de Gilles Deleuze / Augusto Moreira De Carvalho Junior ; orientador: Paulo Cesar Duque Estrada. - 2017. $76 \mathrm{f.} ; 30 \mathrm{~cm}$ Dissertação (mestrado)-Pontifícia Universidade Católica do Rio de Janeiro, Departamento de Filosofia, 2017.

Inclui bibliografia

1. Filosofia - Teses. 2. Simulacro. 3. Representação. 4. Diferença. 5. Eterno retorno. 6. Recognição. I. Estrada, Paulo Cesar Duque. II. Pontifícia Universidade Católica do Rio de Janeiro. Departamento de Filosofia. III. Título. 


\section{Agradecimentos}

Ao CNPQ, pelo apoio através de bolsa para pesquisa e desenvolvimento de estudos, sem o qual não teria sido possível o pleno desenvolvimento da pesquisa e conclusão do mestrado acadêmico a que essa dissertação é referido.

À Paulo Cesar Duque Estrada que além da orientação criteriosa, apoiou e incentivoume nos momentos mais difíceis para que assim fosse possível superá-los e viesse a concluir esta etapa de minha formação acadêmica. 


\section{Resumo}

Junior, Augusto Moreira de Carvalho; Estrada, Paulo César Duque. Novação - Como o mesmo se torna outro? - Representação e Diferença no pensamento de Gilles Deleuze. Rio de Janeiro, 2017. 76 p. Dissertação de Mestrado - Departamento de Filosofia - Pontifícia Universidade Católica do Rio de Janeiro.

A diferença enquanto submetida às amarras do senso comum (identidade, semelhança, oposição e analogia), ou seja, mediada pela inteligência, opera a síntese da representação e, portanto, entra em um ciclo de repetições e recognições inescapáveis do qual apenas um movimento radical, abrupto, aberrante, imediato tem força para romper. De certo modo as filosofias de Husserl, Bergson, Heidegger, entre outros, buscava esse limiar - momento anterior à mediação consciente de uma percepção dada. Bem como a de Nietzsche que vinculava toda mediação a um modelo moral constituído. Desse modo, buscar o outro, como concepção do que se diferencia do mesmo, requer uma recusa às quatro instâncias da mediação sobre a diferença, à custa da impossibilidade ao novo.

\section{Palavras chave}

Simulacro; Representação; Diferença; Eterno Retorno; Recognição; Tempo; Imanência; Campo Transcendental; Atual e Virtual. 


\section{Résumé}

Junior, Augusto Moreira de Carvalho; Estrada, Paulo César Duque. Nouvelletion - Comme le même il devient un autre? - Représentation et différence dans la pensée de Gilles Deleuze. Rio de Janeiro, 2016. 76 p. Dissertação de Mestrado - Departamento de Filosofia - Pontifícia Universidade Católica do Rio de Janeiro.

La différence tout en étant soumis aux contraintes du sens commun (identité, similarité, opposition et analogie), à savoir, la médiation par l'intelligence, opère la synthèse de la représentation et donc entre dans un cycle de répétitions et recognitions inéluctable dont seulement un mouvement radical, abrupte, aberrante, immédiat Il a la force de rompre. D'une certaine manière les philosophies de Husserl, Bergson, Heidegger, entre autres, cherchais ce seuil - temps précédent à médiation consciente d'une perception donnée. Ainsi que celle de Nietzsche qui liait toute médiation à un modèle moral constitué. Ainsi, chercher un autre, comme la conception de ce qui différencie le même, exige un refus à quatre instances de médiation sur la différence au détriment de l'impossibilité de nouvelle si pas le cas nous agissons.

\section{Mots-clés}

Simulacres; Représentation; Différence; Éternel retour; Recognition; Temps;; Immanence; Champ transcendantal; Actuel et virtuel. 


\section{Abstract}

Junior, Augusto Moreira de Carvalho; Estrada, Paulo César Duque (Advisor). Novation - How the same change into the other? - Representation and Difference in thought of Gilles Deleuze. Rio de Janeiro, 2017. $76 \mathrm{p}$. Dissertação de Mestrado - Departamento de Filosofia - Pontifícia Universidade Católica do Rio de Janeiro.

Difference, when subjected to the bonds of common sense (identity, likeness, opposition and analogy), that is, mediated by intelligence, operates the synthesis of representation and therefore enters into a cycle of inescapable repetitions and recognitions of which only a radical movement, Abrupt, aberrant, immediate has the strength to break. In a way, the philosophies of Husserl, Bergson, Heidegger, among others, sought this threshold - a moment prior to the conscious mediation of a given perception. As well as that of Nietzsche who linked all mediation to a constituted moral model. In this way, seeking the other, as a conception of what differentiates itself from the same, requires a refusal of the four instances of mediation over difference, at the expense of impossibility to the new.

\section{Keywords}

Simulacrum; Representation; Difference; Eternal return; Recognition; Time; Immanence; Transcendental Field; Current and Virtual. 


\section{Sumário}

1.Introdução 11

2. A Origem das Representações e a Diferença Fundamental 14

2.1.Platão, Os Gregos 14

2.O Platonismo 15

2.3 Cópias e Simulacros 18

2.4 Representação e Tempos Modernos 21

2.5 Reversão do Platonismo 23

2.6 Nietzsche e o Simulacro 24

2.7 Afirmação que nega - Negação que afirma 27

2.8 Eterno Retorno \& Vontade de Potência 30

3. Conhecimento e Representação 36

3.1 Gênese 36

3.2 Recognição 38

3.3. Teoria Diferencial das Faculdades 41

3.4 A Reversão de Immanuel Kant 44

3.5 A Diferença em Bergson 52

3.6 Imanência e Campo Transcendental 59

3.7 Atual e Virtual 63

4. Conclusão 67

5. Referências bibliográficas 75 


\section{Abreviatura das Obras Citadas}

\section{DELEUZE}

B Bergsonismo; São Paulo: Editora 34, 1999.

CC Crítica e Clínica; São Paulo: Editora 34, 2013.

DR Diferença e repetição; São Paulo: Graal, 2009.

ID A Ilha Deserta; São Paulo: Iluminuras, 2014.

LS Lógica do Sentido; São Paulo: Perspectiva, 2011.

NF Nietzsche e a Filosofia; Rio de Janeiro: Editora Rio, 1976.

\section{DELEUZE e PARNET}

D Diálogos; São Paulo: Escuta, 1998.

\section{DELEUZE e GUATTARI}

MP1 Mil Platôs I; São Paulo: Editora 34, 2011.

QF $\quad$ O que é a Filosofia?; São Paulo: Editora 34, 2010.

\section{NIETZSCHE}

AFZ Assim Falou Zaratustra; Rio de Janeiro: Civilização Brasileira, 2006.

\section{MACHADO}

DAF Deleuze - A Arte e a filosofia; São Paulo: Zahar, 2013.

\section{PELBART}

TNR O Tempo Não-Reconciliado; São Paulo: Perspectiva, 2015.

\section{BERGSON}

PM O Pensamento e o Movente; São Paulo: Martins Fontes, 2006. 
O tempo é a substância de que sou feito. O tempo é um rio que me arrasta, mas eu sou o rio; é um tigre que me destroça, mas eu sou o tigre; é um fogo que me consome, mas eu sou o fogo. O mundo, desgraçadamente, é real; e eu, desgraçadamente, sou...

Jorge Luis Borges, Nova refutação do tempo 


\section{Introdução}

Se nossa capacidade de sentir, e perceber, está intimamente ligada a nossa incapacidade de estabelecer um conhecimento completo e necessário sobre os objetos de conhecimento, se esse conhecimento está diretamente relacionado a representação que fazemos deles e só a partir dela podemos proceder métodos investigativos que nos levem a sua facticidade e utilidade, é, e não poderia ser de outra forma, naquilo que o difere, e não no que o assemelha, que devemos buscar o novo.

O novo só pode aparecer pela diferenciação do que foi no que será, pois, aquilo que permanece continua o mesmo. Assim, apenas no outro - no sentido de não mais o mesmo - podemos buscar a novação.

Ora, o novo surge como aquilo que transforma o mesmo no outro. Essa mudança transforma uma coisa, qualquer coisa (objeto, pessoa, fato, acontecimento...) em algo que difere em quantidade e/ou qualidade daquilo que era anteriormente; essas relações são à base dos estudos científicos, filosóficos, religiosos e principalmente das relações humanas tratadas nessas três áreas, em teorias e pesquisas, bem como pelo senso comum na forma de sabedoria popular em lendas, ditos, mitos e folclores. Dessa forma, trazer essa questão, em um primeiro momento, parece tratar de algo já resolvido ou em vias de se resolver na área a qual essa relação se estabeleça; mas, a novidade carrega em si algo que não se deduz da observação do antecedente e do consequente, pois ela não é nem um nem outro, mas aquilo que proporcionou a transformação. Tampouco poderíamos dizer que é a causa, porque seu efeito é diferenciante, ela não estabelece um princípio único, mas uma infinidade de possibilidades advindas da multiplicidade de condicionantes. Portanto, o olhar sobre o novo deve ser um olhar sobre a diferença. 
Porém, a diferença enquanto submetida às amarras do senso comum (identidade, semelhança, oposição e analogia), ou seja, mediada pela inteligência, opera a síntese da representação e, portanto, entra em um ciclo de repetições e recognições inescapáveis do qual apenas um movimento radical, abrupto, aberrante, imediato tem força para romper. De certo modo as filosofias de Husserl, Bergson, Heidegger, entre outros, buscava esse limiar - momento anterior à mediação consciente de uma percepção dada. Bem como a de Nietzsche que vinculava toda mediação a um modelo moral constituído. Desse modo, buscar o outro, como concepção do que se diferencia do mesmo, requer uma recusa às quatro instâncias da mediação sobre a diferença, à custa da impossibilidade ao novo.

Deleuze dedicou sua obra a esse tema, confrontando diferença com representação; atribuindo a esta última uma diferença ao idêntico que não passa de um reconhecimento representacional de uma oposição ao mesmo. Por isso recorremos a suas análises no desdobramento desta questão.

Através de uma genealogia (diferença-representação) procuraremos analisar o surgimento das representações e de que forma podemos escapar delas com o advento da Filosofia da Diferença. Demonstrar, ainda, o círculo vicioso existente no processo de obtenção de conhecimento que impossibilita pensar os verdadeiros problemas, pois nos coloca de antemão na representação. Para, assim, contribuir com o ultrapassamento de discussões e conflitos entre doutrinas que se diferenciam mais por uma confusão no desdobramento de seus princípios que em uma diferença fundamental destes princípios - como aquela existente entre empirismo e idealismo, ou, ainda, entre objetivismo e subjetivismo. Com o objetivo de compreender a novação em sua potência de produção do novo no mundo, vamos problematizar as relações espacio-temporais, discutindo o tempo como a instância onde a diferença se constitui. Passando, daí, ao plano de imanência onde a plena virtualidade se ramifica em atualidade dando ao tempo suas duas vertentes: o presente que passa; e o passado que se alonga e permanece. 
O assunto aqui tratado está evidentemente no ar, podendo-se ressaltar como sinais disso: a orientação cada vez mais acentuada de Heidegger na direção de uma Filosofia da Diferença Ontológica; o exercício do estruturalismo, fundado numa distribuição de caracteres diferenciais num espaço de coexistência; a arte do romance contemporâneo, que gira em torno da diferença e da repetição não só em sua mais abstrata reflexão como também em suas técnicas efetivas; a descoberta, em vários domínios, de uma potência própria de repetição, potência que também seria a do inconsciente, da linguagem, da arte. Todos estes sinais podem ser atribuídos a um anti-hegelianismo generalizado: a diferença e a repetição tomaram o lugar do idêntico e do negativo, da identidade e da contradição, pois a diferença só implica o negativo e se deixa levar até a contradição na medida em que se continua a subordiná-la ao idêntico. $\mathrm{O}$ primado da identidade, seja qual for a maneira pela qual esta é concebida, define o mundo da representação. Mas o pensamento moderno nasce da falência da representação, assim como da perda das identidades e da descoberta de todas as forças que agem sob a representação do idêntico. (DELEUZE; Diferença $e$ repetição, p.15)

Enquanto a diferença é submetida às exigências da representação, ela não é nem pode ser pensada em si mesma. Deve ser examinada de perto a seguinte questão: foi ela "sempre" submetida a essas exigências e por quais razões? Mas é claro que os puros disparates formam, ou o além celestial de um entendimento divino inacessível a nosso pensamento representativo, ou o aquém infernal, insondável para nós, de um Oceano da dessemelhança. De todo modo, a diferença em si mesma parece excluir toda relação do diferente com o diferente, relação que a tornaria pensável. Parece que ela só se torna pensável quando domada, isto é, quando submetida ao quádruplo cambão da representação: a identidade no conceito, a oposição no predicado, a analogia no juízo, a semelhança na percepção. (DELEUZE; Diferença e repetição, p.365) 


\section{A Origem das Representações e a Diferença Fundamental}

\subsection{Platão, Os Gregos}

A polis grega orgulhava-se de sua autonomia recusando qualquer "transcendência imperial bárbara", formando assim "campos de imanência"”. Pois a philia grega estabelecia uma igualdade como parâmetro de cidadania, isto é, "rivais livres, cujas pretensões entram a cada vez num agón de emulação e se exercem nos domínios mais diversos: amor, atletismo, política, magistraturas."3 Desta forma, a opinião ganha importância em toda Grécia, mas ainda mais em Atenas, cujo modelo de democracia dá as condições ideais para o desenvolvimento da Filosofia e da Sofística: “autoctonia, philia e doxa". Se o filósofo é o amigo e não o detentor da sabedoria é porque a verdade não é possuída por ele, mas é ele que vem propor um método que torne "segura a opinião dos homens", e, com isso, possam construir uma opinião verdadeira. De certa forma esse é o objeto sofista, que além do mais é a herança grega às sociedades democráticas modernas, e, também, o que incomoda Platão na democracia ateniense, pois "todo mundo aí pretende não importa o quê"6 - essa pretensão levou, inclusive, à condenação de Sócrates. ${ }^{7}$ Platão, por isso, não vai apelar para as antigas transcendências míticas ou imperiais e, portanto, terá que criar a sua própria, "uma transcendência que se exerce e se encontra no próprio campo de imanência"8: a teoria das Ideias - teoria da Representação. A transcendência, agora,

${ }^{1} \mathrm{CC}, \mathrm{p} .175$

${ }^{2}$ Idem

${ }^{3}$ Ibid

${ }^{4}$ Ibid

${ }^{5} \mathrm{CC}, \mathrm{p} .176$

${ }^{6}$ Idem

7 Sócrates através de um método próprio buscava verificar a veracidade de um postulado confrontando-o com a opinião daquele que, de certo modo, tivesse sido reconhecido como apto e, portanto, imputado a proferi-la.

${ }^{8}$ CC, p. 176 
introduzida no corpo da Filosofia é revestida de um sentido que a torna plausível. E isso levou a uma ideia de superioridade da Filosofia sobre outras instâncias do conhecimento, contaminando a Filosofia até os dias de hoje.

O platonismo se apresenta como a Filosofia dos duplos, consiste na distinção entre: essência e aparência, inteligível e sensível, original e cópia, ideia e imagem; método que marca a história da Filosofia fazendo da oposição entre essência inteligível e aparência sensível, todo o desenvolvimento da filosofia em busca de uma verdade, verdadeira, que não poderia vir da aparência sensível, pois os estímulos sensíveis, para este modelo, são obstáculos ao pensamento porque indicam apenas um assentimento com a cópia. E, se o platonismo é a Filosofia dos duplos em sua interioridade, ela tem na Sofística o seu próprio duplo como exterioridade.

\begin{abstract}
A inteligibilidade de uma coisa, em vez de ser um resultado da violência da sensibilidade, que faz pensar, que força o pensamento, é dada pelo afastamento do sensível. (MACHADO; Deleuze - A Arte e a filosofia, p.42)
\end{abstract}

\title{
2.2 O Platonismo
}

O método platônico é antes de tudo um método de divisão. É a partir da divisão como método que Platão concebe reunir "toda potência da dialética, para fundi-la com uma outra potência [mítica] e representa, assim, todo o sistema."9 A dialética platônica como filosofia dos duplos, de oposição mútua entre esses duplos, ou de suas contradições e contrariedades aparece apenas como uma de suas faces, a que se mostra em primeiro lugar, a mais pobre e que não suporta a objeção aristotélica quanto a falta de um termo médio configurando-se por isso em um mal silogismo. Mas em Platão “o objetivo da divisão não é, pois, em absoluto, dividir um gênero em espécies, mas, mais profundamente, selecionar linhagens: distinguir os pretendentes,

${ }^{9}$ LS, p.259 
distinguir o puro e o impuro, o autêntico e o inautêntico"10; O platonismo busca assim, distinguir os verdadeiros dos falsos pretendentes e, portanto, seu método de divisão pode ser considerado como uma amphisbetesis ${ }^{11}$ : "O único problema que atravessa toda a Filosofia de Platão, é sempre o de avaliar os rivais, de selecionar os pretendentes, de distinguir a coisa e seus simulacros no seio do pseudogênero ou de uma espécie ampla demais." 12

Platão se utiliza, ainda, do mito para reforçar a imagem de seleção e escolha pelos verdadeiros pretendentes, como se a verdade viesse a transcender daí em si mesma. $\mathrm{O}$ mito, então, aparece como o modelo imanente com o qual os pretendentes serão julgados e sua pretensão medida. "E é sob esta condição que a divisão prossegue e atinge seu fim, que é não a especificação do conceito mas a autenticação da Ideia"13. Daí, também a crítica de Aristóteles, pois a falta de um mediador na divisão traz a necessidade do mito para cumprir-lhe o papel. Porém, aí se configura o engano pois, é a divisão "que sobrepuja a dualidade e integra o mito na dialética"14; modelo que aparece claramente nas obras de Platão, por exemplo: no Fedro, quando as almas se deparam com a forma pura das Ideias, ou no Político "sob a forma do Deus-pastor que preside o movimento circular do universo." 15 É assim que a profundidade do método da divisão aparece em segundo lugar, fazendo do mito o elemento de fundação que estabelece a diferença, e, inversamente, a diferença como o estado daquilo que deve ser fundado. "A divisão é a verdadeira unidade da dialética e da mitologia, do mito como fundação..."16

[...] quando a divisão chega a esta verdadeira tarefa seletiva, tudo se passa como se ela renunciasse em cumpri-la e se deixasse substituir por um mito. [...] Tal é a segunda armadilha da divisão, sua segunda ironia,

\footnotetext{
${ }^{10}$ LS, p.260

${ }^{11}$ Idem; dialética da rivalidade.

${ }^{12}$ DR, p.99

${ }^{13}$ LS, p.261

${ }^{14}$ DR, p. 101

${ }^{15}$ Idem

${ }^{16} \mathrm{Ibid}$
} 
esta escapada, esta aparência de escapada ou de renuncia. [...] É próprio da divisão ultrapassar a dualidade entre o mito e a dialética e reunir em si a potência dialética e a potência mítica. $\mathrm{O}$ mito com sua estrutura sempre circular, é realmente a narrativa de uma fundação. É ele que permite erigir um modelo segundo o qual os diferentes pretendentes poderão ser julgados. (DELEUZE; Lógica do sentido, p.260)

O fundamento no platonismo é o que resolve a questão da mediação na divisão e a partir dele que se desenvolve a concepção de participação. A participação é o que aparece como delegado, o fundamento é aquilo que pode delegar. Então, temos no platonismo as Ideias em primeiro lugar como fundamento, e os participantes, aqueles que vêm a ter parte em segundo, terceiro, quarto lugar, ou, ainda, em simulacro. "O fundamento é uma prova que dá aos pretendentes uma participação maior ou menor no objeto da pretensão; é neste sentido que o fundamento mede e estabelece a diferença." 17

É curioso que dos textos platônicos sobre a divisão $O$ Sofista seja o único que não se utilize de um mito fundador. Mas isto ocorre porque no Sofista Platão não busca avaliar os justos pretendentes, mas ao contrário, "encurralar o falso pretendente como tal, para definir o ser (ou antes o não-ser) do simulacro"18; e assim, como nos mitos épicos, "os falsos pretendentes devem morrer."19

Mas, neste sentido, é possível que o fim do Sofista contenha a mais extraordinária aventura do platonismo: à força de buscar do lado do simulacro e de se debruçar sobre seu abismo, Platão, no clarão de um instante, descobre que não é simplesmente uma falsa cópia, mas que põe em questão as próprias noções de cópia . . . e de modelo. (DELEUZE; Lógica do sentido, p.261)

\footnotetext{
${ }^{17}$ DR, p. 102

${ }^{18}$ LS, p. 261

${ }^{19}$ DR, p.99
} 
“O não na expressão não-ser, exprime alguma coisa distinta do negativo."20 Costumamos afirmar: só o Ser existe!; o não-ser, portanto, como negativo do Ser, deve sua existência ao $\operatorname{Ser}^{21}$. O Ser, então, é a própria essência do problema. No platonismo o Ser, ou a Ideia, como preferir, é o próprio fundamento, mas também é a questão como essência do problema. "Nesta relação, o ser é a própria Diferença. O ser é também não-ser, mas o não-ser não é o ser do negativo, é o ser do problemático, o ser do problema e da questão." 22

As quatro figuras da dialética platônica são, portanto, as seguintes: a seleção da diferença, a instauração de um círculo mítico, o estabelecimento de uma fundação, a posição de um complexo questão-problema. (DELEUZE; Diferença e repetição, p.105)

\subsection{Cópias \& Simulacros}

Platão dá a Ideia um estatuto de qualidade primeira - necessária e universal; e, a partir dela, poderá ser determinado aquilo que participa com qualidade segunda, ou terceira, conforme a natureza da participação. Para tanto, Platão, estabelece uma distinção rigorosa entre modelo e cópia, distinção esta que ultrapassa a simples aparência; pois, a cópia tem uma relação intima com o modelo, enquanto o simulacro mantém com a cópia apenas a relação de aparência, “a da própria cópia e do fantasma" 23 .

"As cópias são possuidoras em segundo lugar, pretendentes bem fundados, garantidos pela semelhança;" 24 pois na cópia reside uma relação direta com a essência, algo que

\footnotetext{
${ }^{20}$ DR, p. 103

${ }^{21}$ Deleuze amplia a questão: "ou não há não-ser, e a negação é ilusória e não fundada; ou há não ser, que põe o negativo no ser e funda a negação" (DR, p.103), porém daí implicaria uma determinação subjetiva que não está em questão.

${ }^{22}$ Idem

${ }^{23}$ DAF, p.45

${ }^{24}$ LS, p. 262
} 
a primeira carrega e manifesta na segunda. E assim, a copia é fundada pela semelhança interna com a identidade superior da ideia. "Os simulacros são como os falsos pretendentes, construídos a partir de uma dissimilitude, implicando uma perversão, um desvio essenciais." ${ }^{25}$ Assim, podemos dizer que o objetivo de Platão se concentra na seleção dos pretendentes, enquanto no plano sensível, pois, a partir da distinção das boas e das más cópias parte à associação: das primeiras com as essências puras, representações da verdade no difuso plano das sensações; e das segundas, simulacros, cópia das cópias, cópia em segundo grau, cópia das aparências, das dessemelhanças, do falso. Trata-se, para Platão, “de assegurar o triunfo das cópias sobre os simulacros, de recalcar os simulacros, de impedi-los de subir à superfície e de se 'insinuar' por toda parte." 26

Em Platão temos uma primeira dualidade à distinção manifesta entre mundo das essências e mundo das aparências e outra mais fundamental, uma distinção latente entre as boas cópias e os simulacros. "A grande dualidade manifesta, a Ideia e a imagem, não está aí senão com este objetivo: assegurar a distinção latente entre as duas espécies de imagens, dar um critério concreto." ${ }^{27}$ Pois, dotadas de semelhança, as cópias se fundam pela identidade superior da Ideia, sobre uma semelhança interna ou derivada. Por fim, a cópia, na medida em que reproduz o modelo, poderia ser considerada uma mera imitação; “contudo, como esta imitação é noética, espiritual e interior, ela é uma verdadeira produção que se regula em função das relações e proporções constitutivas da essência." 28

Deus fez o homem à sua imagem e semelhança, mas, pelo pecado, o homem perdeu a semelhança embora conservasse a imagem. Tornamo-nos simulacros, perdemos a existência moral para encontrarmos a existência estética. (DELEUZE; Lógica do sentido, p. 263)

\footnotetext{
${ }^{25}$ LS, p. 262

${ }^{26}$ Idem

${ }^{27}$ Ibid

${ }^{28}$ LS, p.263
} 
No platonismo os simulacros adquirem o direito a subverterem a filosofia da representação através de uma potência positiva, opondo ao invés de uma subordinação a relação essência-aparência, a destruição das categorias de original e cópia.

"O simulacro nega tanto o original quanto a cópia, é a imagem sem semelhança." ${ }^{29} \mathrm{E}$ assim, o simulacro rompe com o modelo em que a cópia deriva de uma semelhança essencial da Ideia que a funda, para uma semelhança superficial, de conjunto, pois, que, é "construído sobre uma diferença"30; o que é interno ao simulacro é a disparidade, a dissimilitude. Nele não encontramos uma relação nem mesmo com a cópia, se o relacionarmos a um modelo este seria outro, "um modelo do Outro de onde decorre uma dessemelhança interiorizada."31 E o próprio Platão vai explicar essa dificuldade, ou melhor, de que modo o simulacro traz consigo um conhecimento improdutivo, "obtido por ardil ou subversão" 32 , praticado pelos sofistas: "o simulacro implica grandes dimensões, profundidades e distâncias que o observador não pode dominar"33; e, por isso, dá uma impressão de semelhança; o próprio observador passa a fazer parte do simulacro, fazendo com que seu ponto de vista torne-se a diferença deformando-o e transformando-o em um devir ilimitado, um devir louco, "um devir sempre outro, um devir subversivo, das profundidades, hábil a esquivar o igual, o limite, o Mesmo ou o Semelhante: sempre mais e menos ao mesmo tempo, mas nunca igual." 34

Audouard mostrou muito bem este aspecto: os simulacros "são construções que incluem o ângulo do observador, para que a ilusão se produza do ponto mesmo em que o observador se encontra... Não é na realidade o estatuto do não-ser que é enfatizado, mas neste pequeno desvio, da imagem real, que se prende do ponto de vista ocupado pelo observador e que

\footnotetext{
${ }^{29}$ DAF, p.49

${ }^{30}$ LS, p. 263

${ }^{31}$ Idem

${ }^{32}$ LS, p. 264

${ }^{33}$ Idem

${ }^{34}$ Ibid
} 
constitui a possibilidade de construir o simulacro, obra do sofista" (("Le Simulacre", Cahiers pour l'analyse, $\mathrm{n}^{\circ}$ 3) apud DELEUZE, Lógica do Sentido, p.264)

\subsection{Representação e Tempos Modernos}

É a partir do platonismo como doutrina que a filosofia se debruçará e desdobrará, alcançando outros graus, ampliando o domínio da Representação do finito ao infinito: "sob a influência do Cristianismo, não se procura mais somente fundar a representação, mas torná-la infinita, fazer valer para ela uma pretensão sobre o ilimitado, abrindo-a sobre o Ser." 35 Com a Representação, "fundar é determinar"36; o fundamento como Essência Ideal se define como idêntico, pois traz em si a diferença de seu objeto. A Diferença, que é a qualidade que o fundamento possui em primeiro lugar, é o que o fundado vai possuir em segundo lugar, na forma de semelhança. "A diferença é aqui pensada sob o princípio do Mesmo e sob a condição da semelhança". ${ }^{37}$ A imagem bem fundada vai chamar-se representação, pois, em relação ao fundamento, será primeira em sua ordem e, ainda, será segunda em si. De outro modo, a partir da fundação do mundo das representações, o fundamento não se definirá mais através do idêntico, pois ele já se tornou o caráter interno da própria representação, bem como sua relação exterior tornou-se a semelhança. Então, o objeto de pretensão não é a diferença como qualidade, mas o inquantificável; é aquilo que vai se estabelecer na diferença do grande demais e do pequeno demais, na pretensão da representação alcançar o infinito. "Contudo, se ainda assim não saímos do elemento da representação é porque permanece a dupla exigência do Mesmo e do Semelhante"38; por um lado o Mesmo, através do princípio de razão suficiente, encontra o modo de governar o ilimitado; e, por outro, a convergência, ou continuidade, torna-se a condição do Semelhante se aplicar ao ilimitado.

\footnotetext{
${ }^{35}$ LS, p. 265

${ }^{36}$ DR, p. 377

${ }^{37}$ DR, p. 378

${ }^{38}$ LS, p.265
} 
Leibniz e Hegel intentaram escapar, mas ao submeterem seus modelos a um só centro acabaram sucumbindo à representação.

Vemos, pois como Leibniz exclui a divergência distribuindo-a em "incompossíveis" e conservando o máximo de convergência ou de continuidade como critério do melhor mundo possível, isto é, do mundo real. Da mesma forma, para Hegel, mostrou-se recentemente até que ponto os círculos da dialética giravam em torno de um só centro. (DELEUZE; Lógica do sentido, p.265)

O que vemos, nesses exemplos, é que “a filosofia não deixa o elemento da representação quando parte à conquista do infinito"39, adaptando-se às exigências especulativas do Cristianismo, do infinitamente pequeno e do infinitamente grande, em busca de um telos, uma finalidade superior, "de uma realidade essencial ou mesmo de um sentido da história" ${ }^{40}$; isolando, para tanto, o divergente ou excluindo o excêntrico. Mas, o simulacro é o signo que rompe essas cadeias, pois ao se apresentar como Outro produz uma espécie de ressonância interna ${ }^{41}$ que transborda as séries afirmando sua potência de fantasma ${ }^{42}$, livrando-as da monocentragem do modelo representacional. ${ }^{43}$

Os sistemas que operam através dos simulacros e, portanto, formam séries heterogêneas através de elementos díspares ${ }^{44}$, são sistemas sinal-signo ${ }^{45}$. "O sinal é uma estrutura em que se repartem diferenças de potencial e que assegura a Joyce por exemplo; "Reúnem-se as condições da experiência real e as estruturas da obra de arte: divergência das séries, descentramento dos círculos, constituição do caos que os compreende, ressonância interna e movimento de amplitude, agressão dos simulacros” (LS, p.266)

${ }^{44}$ Idem

45 Ibid
} 
comunicação dos díspares; o signo é o que fulgura entre os dois níveis da orla, entre as duas séries comunicantes" ${ }^{\prime 6}$.

Parece realmente que todos os fenômenos respondem a estas condições na medida em que encontram sua razão em uma dissimetria, em uma diferença, uma desigualdade constitutivas: todos os sistemas físicos são sinais, todas as qualidades são signos. (DELEUZE; Lógica do sentido, p.266)

Nas fórmulas: "só o que parece difere" e "somente as diferenças se parecem"; temos duas formas de relação com o mundo, à primeira submetida ao Mesmo representação; a segunda, sem fixidez, a uma relação em que o que se assemelha é aquilo que difere, ou melhor, o próprio movimento de diferir é o que o assemelha simulacro.

\subsection{Reversão do Platonismo}

Para entender a radicalidade do simulacro é preciso mergulhar no caos da heterogenia das séries e da diferença não submetida à representação. É curioso que Platão foi o primeiro a perceber que o simulacro colocava em risco seu projeto Ideal, daí, portanto, também foi Platão quem estabeleceu as condições para que a "Reversão do platonismo", solicitada por Nietzsche, pudesse ser colocada em prática. "Reverter o platonismo significa então: fazer subir os simulacros, afirmar seus direitos entre os ícones ou as cópias". ${ }^{47}$ A distinção entre essência e aparência torna-se pequena, fraca, para dar conta do aparecimento insinuante das séries discordantes, pois, que, já não figura em uma relação com o estabelecido, mas como aquilo que diverge que rompe com o estabelecido e, portanto, não traz em si qualquer relação essencial. "O simulacro não é uma cópia degradada, ele encerra uma potência positiva que nega

\footnotetext{
${ }^{46}$ Ibid

${ }^{47}$ LS, p. 267
} 
tanto o original como a cópia, tanto o modelo como a reprodução" ${ }^{48}$. Nenhuma série pode ser dita cópia ou origem, o simulacro rompeu as hierarquias platônicas das ideias (primeira, segunda, terceira ordens). "Na reversão do platonismo, é a semelhança que se diz da diferença interiorizada, e a identidade do Diferente como potência primeira. [...] Trata-se do falso como potência."49

Mas, o falso traz consigo a ideia, o peso, de algo que corrompe a identidade verdadeira que ele falseia, estabelecendo, assim, um modelo de verdade do qual retira sua identidade (e poderíamos dizer também sua semelhança), porém, aqui, o falso pretendente não estabelece essa relação visto que ela foi rompida em sua inessencialidade. É, podemos dizer, "o triunfo do falso pretendente." ${ }^{50}$ É o fantasma maquinista de uma máquina dionisíaca, é o simulacro como efeito do seu funcionamento. Portanto, subir os simulacros significa derrubar a ordem das participações e a hierarquia entre modelo e cópia, sob, como nos diz Nietzsche: a mais alta potência do falso ${ }^{51}$.

\subsection{Nietzsche e o simulacro}

Posto, que a "simulação designa a potência para produzir um efeito," 52 ela traz em si um disfarce - pois se a situarmos como um nexo causal estabeleceríamos novamente uma relação de continuidade, como a de modelo e cópia; o eterno retorno. É ele quem vai proporcionar a condição para uma passagem do conteúdo manifesto do platonismo para um conteúdo latente. "O conteúdo manifesto do eterno retorno pode ser determinado ao platonismo em geral" ${ }^{, 53}$, pois representa a vinculação do Mesmo com o Semelhante, ou seja, uma organização do Caos calcada no modelo da Ideia;

\footnotetext{
${ }^{48}$ Idem

${ }^{49}$ LS, p. 268

${ }^{50}$ Idem

${ }^{51}$ LS, p.268

${ }^{52}$ Idem

${ }^{53}$ LS, p. 269
} 
neste sentido, o eterno retorno, é o “devir louco controlado, monocentrado, determinado a copiar o eterno" $" 54$. Mas, o eterno retorno traz ainda um viés oculto: seu conteúdo latente; que é a potência de afirmar o $\operatorname{caos}^{55}$.

Se "eterno retorno" lembra um movimento circular, remetendo a um círculo monocentrado, e, assim, conformado às Ideias platônicas; pois, indicaria uma determinação transcendente, um ser essencial que suportaria as condições de sobrevivência e manutenção da verdade; ele assim se parece somente enquanto conformado a primeira etapa de seu voo radical. A identidade que surge daí é projetada a partir de uma semelhança forjada no simulacro, portanto, sobre o divergente. Tal identidade não adquire relação de semelhança com nenhuma matriz, nem mesmo com o simulacro, pois este, como tal, já se diferenciou de si mesmo; ele não guarda nenhum conteúdo essencial que lhe proporcionasse fixidez. O que retorna, portanto, "são as séries divergentes enquanto divergentes" que difere.

O eterno retorno é, pois, efetivamente o Mesmo e o Semelhante, mas enquanto simulados, produzidos pela simulação, pelo funcionamento do simulacro (vontade de potência). É neste sentido que ele subverte a representação, que destrói os ícones: ele não pressupõe o Mesmo e o Semelhante, mas, ao contrário, constitui o único Mesmo daquilo que difere, a única semelhança do desemparelhado. Ele é o fantasma único para todos os simulacros (o ser para todos os entes). É potência para afirmar a divergência e o descentramento. (DELEUZE; Lógica do sentido, p.270)

Nietzsche associava as ideias de caos e eterno retorno como uma mesma ideia ${ }^{57}$. O eterno retorno, assim como o caos, implica em um mundo sem identidade, onde as

\footnotetext{
${ }^{54} \mathrm{Idem}$

${ }^{55}$ Ibid

${ }^{56}$ LS, p. 270

${ }^{57}$ Como o caosmos do vicus of recirculation de Joyce.
} 
diferenças imbricam umas nas outras, em uma "caos-errância"58 que vai comprometer, em último caso, a possibilidade de uma representação de mundo e de sujeito. Na representação o mundo aparece entre dois horizontes: o infinito e a finitude; o transcendente e o imanente subjugado. No eterno retorno, o mundo não é nem um nem outro, “é o ilimitado do próprio acabado, o ser unívoco que se diz da diferença" ${ }^{\text {"59 }}$. É imanência pura, não ontologizada porque não se submete a qualquer transcendência, mas que pode ser dita pela diferença enquanto movimento, ou ainda, enquanto série divergente. Assim, associar ontologicamente o simulacro é conformálo ao Ser, o que já pressuporia uma transcendência. Mas o ser do simulacro é o eterno retorno - o eterno retorno é o ser imanente; e, portanto, atravessado em um simulacroente, destrói a coerência na representação destruindo, assim, a ideia de Ser-sujeito.

O que exprime o eterno retorno é esse novo sentido da síntese disjuntiva. Da mesma forma o eterno retorno não se diz do Mesmo ("ele destrói as identidades"). Ao contrario, ele é o único Mesmo, mas que se diz do que difere em si - do intenso, do desigual, ou do disjunto (vontade de potência). Ele é realmente o Todo, mas que se diz do que permanece desigual; a Necessidade, que se diz somente do fortuito. Ele próprio é unívoco: ser, linguagem ou silencio unívocos. Mas o ser unívoco se diz de existentes que não o são, a linguagem unívoca se aplica a corpos que não o são, o silencio "puro" envolve palavras que não o são. Procuraríamos, pois, em vão no eterno retorno a simplicidade de um circulo, assim como a convergência das séries em torno de um centro. [...] Assim, o eterno retorno é realmente o Todo, mas o todo que se diz dos membros disjuntos ou séries divergentes; ele não faz voltar tudo, não faz voltar nada do que volta uma vez, do que pretende recentrar o círculo, tornar as séries convergentes, restaurar o eu, o mundo e Deus. (DELEUZE, Lógica do Sentido, p.308309)

Nietzsche parece ser de fato o primeiro a ver que a morte de Deus só se torna efetiva com a dissolução do Eu. O que então se revela é o ser que se diz de

\footnotetext{
${ }^{58}$ DR, p. 95
}

${ }^{59}$ DR, p. 94 
diferenças que nem estão na substancia nem no sujeito: outras tantas afirmações subterrâneas. (DELEUZE;

Diferença e repetição, p.96)

\subsection{Afirmação que nega, Negação que afirma}

A Filosofia da Diferença recusa uma alternativa geral da Representação Infinita: “o indeterminado, o indiferente, o indiferenciado, ou uma diferença já determinada como negação." ${ }^{60}$ A Diferença, nela mesma, é afirmação; assim como, a Afirmação, nela mesma, é diferença. De outra forma, podemos dizer que a "negação é o motor e a potência. A afirmação resulta daí - como um ersatz ${ }^{61}$, digamos." ${ }^{\circ 2}$ Assim, quando a negação afirma a diferença, é a própria negação que está sendo afirmada pois, o que se afirma na negação é aquilo mesmo que se quer negado. Inversamente, a Diferença é afirmação por negar a afirmação, retirando dela a possibilidade de fixidez, mantendo-a em constante devir, devir indeterminado, portanto descentrado. "Nietzsche assinala o conservadorismo assustador de uma tal concepção"63.

Há um gosto terrível pela responsabilidade nesse asno [de Zaratustra] ou nesse boi dialético e um ranço moral, como se fosse preciso passar pelas infelicidades da cisão e do dilaceramento para chegar a dizer sim; como se a Diferença fosse o mal e como se ela fosse o negativo que só poderia produzir a afirmação expiando, isto é, encarregando-se, ao mesmo tempo, do peso do negado e da própria negação. Sempre a velha maldição a retumbar do alto do princípio de identidade... (DELEUZE; Diferença e repetição, p.90)

“A afirmação é de fato produzida, mas para dizer sim a tudo o que é negativo e negador, a tudo que pode ser negado." ${ }^{64}$ Desta forma, o que está sendo afirmado é o

\footnotetext{
${ }^{60}$ DR, p.89

${ }^{61}$ Do alemão: Substituto, equivalente...indenização, recolocação.

${ }^{62}$ DR, p. 90

${ }^{63}$ Idem

${ }^{64}$ DR, p. 90
} 
espírito de carregação, de Assumpção ${ }^{65}$, de gravidade (o peso, a culpa ancestral); implica em um niilismo. Esse é o círculo dialético da representação infinita, monocentrado, círculo de conservação da memória, círculo de repetição. "A repetição neste caso nada mais é que um conservatório, uma potência da própria memória." 66 Por isso Nietzsche vai definir Kant e Hegel como: "operários da Filosofia"; pois, reféns do negativo, "acumulam e conservam uma massa enorme de juízos de valores estabelecidos"67 - manutenção na representação infinita daquele que carrega e daquilo que é carregado. Mas, ao contrário, a Diferença como afirmação traz o Não como seu signo. Sem repetições ou sujeições apenas leveza em sua ação afirmadora. "Já não é o negativo que produz um fantasma de afirmação, como um ersatz. É o Não que resulta da afirmação: ele é, por sua vez, a sombra" ${ }^{68}$, o nachfolge $^{69}$.

O eterno retorno é o nachfolge da negação estabelecendo da diferença "a forma superior de tudo que é"70 por operar no limite extremo, lá onde os novos valores surgem. Nietzsche reforça sua crítica a filosofia precedente, censurando os "procedimentos de seleção fundados na oposição ou no combate"71 por operarem sobre as formas médias; essas trazem uma diferença com as formas extremas que não é de grau, mas de natureza, "como entre a ordem conservadora da representação e uma desordem criadora, um caos genial, que só pode coincidir com um momento da história sem confundir-se com ele". ${ }^{72}$ Assim, quando nos referimos às doutrinas de Platão, Kant, Nietzsche, ou de qualquer outro filósofo precisamos ter como horizonte a finitude de suas instaurações. São únicas, como únicos foram os momentos onde se deram. Retornar a seus conceitos não é, de forma alguma, retornar a elas mesmas, ou fazer desse movimento uma representação em que, a partir dele, pudéssemos repeti-

\footnotetext{
${ }^{65}$ No sentido de assentimento e no arcaico-religioso: "Ele carrega tudo: os fardos de que é encarregado (os valores divinos), aqueles de que ele próprio se encarrega (os valores humanos) e o peso de seus músculos fatigados, quando nada mais tem para carregar (a ausência de valores).” (DR, p.90)

66 Idem

67 Ibid

${ }^{68}$ DR, p.91

${ }^{69}$ No sentido de consequência. (Idem)

${ }^{70}$ DR, p.92

${ }^{71}$ Idem

72 Ibid
} 
las todas as vezes que fossem lembradas, descritas, estudadas, ou seja, transformá-lo em uma representação infinita - o platonismo só ocorreu uma vez ${ }^{73}$. Pois, não é na memória que se encontra o eterno retorno, mas sim "no desperdício, no esquecimento tornado ativo"74.

Tudo o que é negativo e tudo o que nega, todas estas afirmações médias que carregam o negativo, todos esses pálidos Sim mal vindos que saem do não, tudo o que não suporta a prova do eterno retorno, tudo isto deve ser negado. (DELEUZE; Diferença e repetição, p.92)

"A representação tem apenas um centro, uma perspectiva única e fugidia, ela mediatiza tudo, mas não mobiliza nem move nada."75 Já o movimento não se limita a um único centro, ao contrário, necessita de uma multiplicidade de centros, "superposição de perspectivas, imbricação de pontos de vista"76, cada movimento, então, precisa gerar uma representação própria; porém a representação infinita "assegura a convergência de todos os pontos de vista sobre um mesmo objeto, ou um mesmo mundo, ou, ainda, porque faz de todos os momentos um mesmo Eu"77; sobrepondo, assim, uma infinidade de representações a um único centro: a série que ela organiza e que a torna possível. ${ }^{78}$ Para escapar a este modelo, não basta atacar a representação infinita criando um novo sistema filosófico (doutrinário) que tem como horizonte de atuação a série representacional descrita, criando, assim, um novo centro, tornando-se em nova série - isso, no caso de seu intento se mostrar afortunado; é preciso, ao contrário, voltar a representação particular e descentrá-la. "É preciso que cada ponto de vista seja ele mesmo a coisa ou que a coisa pertença ao ponto de vista. [...] É preciso que a diferença se torne o elemento, a última unidade,

\footnotetext{
73 “Convém que nos interessemos menos por aquilo que se passa antes e depois de Kant e mais pelo momento preciso do kantismo, momento furtivo fulgurante que não se prolonga nem mesmo em Kant, que se prolonga ainda menos no pós-kantismo" (DR, p.96)

${ }^{74}$ Ibid

${ }^{75}$ DR, p.93

${ }^{76}$ Idem

${ }^{77}$ Ibid

78 "a forma do conceito como forma de identidade que constitui ora o em-si do representado (A é A), ora o para-si do representante $(\mathrm{Eu}=\mathrm{Eu})$ " (Ibid)
} 
que ela remeta, pois, a outras diferenças que nunca a identificam, mas a diferenciam."79

Cada coisa, cada ser deve ver sua própria identidade tragada pela diferença, cada qual sendo só uma diferença entre as diferenças. É preciso mostrar a diferença diferindo. (DELEUZE; Diferença $e$ repetição, p.92)

É estranho que se tenha podido fundar a estética (como ciência do sensível) no que pode ser representado no sensível. [...] na verdade, o empirismo se torna transcendental e a estética se torna uma disciplina apodítica quando apreendemos diretamente no sensível o que só pode ser sentido, o próprio ser do sensível: a diferença, a diferença de potencial, a diferença de intensidade como razão do diverso qualitativo. É na diferença que o fenômeno fulgura, que se explica como signo; e que o movimento se produz como "efeito". (Idem)

\subsection{Eterno Retorno \& Vontade de Potência}

Quando os dados lançados afirmam uma vez o acaso, os dados que caem afirmam necessariamente o número ou o destino que traz de volta o lance de dados. É nesse sentido que o segundo tempo do jogo é também o conjunto dos dois tempos ou o jogador que vale para o conjunto. O eterno retorno é o segundo tempo, o resultado do lance de dados, a afirmação da necessidade, o número que reúne todos os membros do acaso, mas também o retorno do primeiro tempo, a repetição do lance dos dados, a reprodução e a reafirmação do próprio acaso. (DELEUZE; Nietzsche e a filosofia, p.23)

Apresentamos, a pouco, o eterno retorno a partir de dois vieses, duas interpretações conflitantes; uma: o conteúdo manifesto, que o apropria como aquilo que retorna 
inexoravelmente ao mesmo; a outra: o conteúdo latente, que retorna também inexoravelmente, mas, ao diferente. É certo que Nietzsche raramente fala a respeito, e, quando o faz se atém ao conteúdo manifesto: "o eterno retorno como o Mesmo que faz voltar o Semelhante"80; a não ser em algumas passagens de Assim Falou Zaratustra, em que Zaratustra mostra sua animosidade, irritação e impaciência confrontando o sentido das duas interpretações, como, por exemplo, na seguinte passagem:

Alto lá, anão, falei. "Ou eu ou tu! Mas eu sou o mais forte dos dois. Você não conhece meu pensamento abismal. Esse - não poderias suportá-lo!" Então, aconteceu algo que me aliviou; pois o anão, curioso como era, pulou de minhas costas ao solo. E se foi acocorar em uma pedra à minha frente. Mas tínhamos parado, justamente, diante de um portal. "Olha esse portal, anão", prossegui; "ele tem duas faces. Dois caminhos se juntam aqui; ninguém ainda os percorreu até o fim. Esse longo caminho que vai para trás dura uma eternidade. E aquele longo caminho que vai para frente é outra eternidade. Esses caminhos se contradizem; encontram-se de frente; e é aqui nesse portal que eles se juntam. O nome do portal está escrito no alto: instante. Mas se alguém seguisse por um desses caminhos sem parar e cada vez mais longe, você pensa, anão, que eles iriam contradizer-se eternamente?". O anão, responde então que o tempo é um círculo; Zaratustra o chama, por isso, de espírito de gravidade, e continua sua exposição: "Olha esse instante. A partir desse portal chamado instante um longo, eterno caminho se estende para trás: há uma eternidade às nossas costas. Tudo o que pode caminhar não deve necessariamente ter uma vez percorrido esse caminho? Tudo o que pode, entre as coisas, acontecer não deve uma vez já ter acontecido, passado, transcorrido? E se tudo já existiu, que acha você, anão, desse instante? Esse portal também não deve já ter existido? E todas as coisas não estão tão firmemente encadeadas que esse momento arrasta consigo todas as coisas futuras? Portanto - também a si mesmo? Porque tudo aquilo que pode caminhar deverá ainda percorrer uma vez também este longo caminho que leva para a frente!" (NIETZSCHE; Assim Falou Zaratustra, p.193)

${ }^{80}$ LS, p.269 
O conteúdo manifesto está aqui associado à fala do anão: o tempo é um círculo; pois, subtende um retornar constante, indiferenciado, e, portanto, vicioso que faz parte do sentido que os antigos faziam do tempo cíclico nos períodos lunares, nas estações do ano, na própria oposição entre dia e noite. Esta ideia leva, consequentemente, a um determinismo que necessita de um eixo (um centro) para, assim, estabelecer uma relação causal entre todos e, ainda, consigo mesmo. Desse modo, o eterno retorno estaria vinculado à identidade, pois o que retorna, assim o faz naquilo que fora, ou melhor, torna ao ser o que nele reconhece, torna-se de novo. Esse é o espírito de peso, ou, gravidade, pois encadeia tudo em uma ordenação de simetria invariável.

O conteúdo latente do eterno retorno surge então, como possibilidade de subordinação à doutrina defendida por Nietzsche, como sua ideia mais original, visto que não poderíamos resumi-la ou subordiná-la a um "pensamento do idêntico - alvo maior da crítica nietzschiana." 81 . A conclusão da fala de Zaratustra ao anão, na passagem citada - "Portanto - também a si mesmo?"; interpõe uma condição ao movimento de retornar que submete o próprio eixo do movimento ao movimento como um puro devir, estabelecendo, para tanto, um novo eixo, um novo centro a partir do qual o todo descrito por Zaratustra possa retornar. O movimento, então, percebe-se múltiplo, pois não se refere mais a um único centro, mas a tantos quantos movimentos houver... ao infinito! Portanto diferindo do anterior como um retornar eterno ao diferente - estamos sempre neste portal "chamado instante", olhando para um passado, determinado, e para um futuro aberto às possibilidades das escolhas intrínsecas do que invariavelmente retorna, mas, em um horizonte movente fazendo da diferença a possibilidade de um retornar novo. O movimento tornou-se acentrado, descentrado; o retornar tornou-se um revir do devir. No conteúdo manifesto o revir era o que se mantinha da mesma forma, era o mesmo. Quando passamos ao conteúdo latente do eterno retorno, a identidade não dita mais àquilo que revém, ao contrário, a

${ }^{81}$ TNR, p.132 
identidade é o próprio revir, é o retorno da diferença. "A lição do eterno retorno é a de que não há o retorno do negativo. O eterno retorno significa que o ser é seleção." ${ }^{82}$ Porém, o eterno retorno necessita de seu par conceitual: a vontade de potência ${ }^{83}$.

"Nietzsche chama vontade de poder o elemento genealógico da força. Genealógico quer dizer diferencial e genético." ${ }^{\text {} 84} \mathrm{O}$ elemento diferencial é um princípio de produção da diferença de quantidade entre as forças. O elemento genético é o principio de qualidade que cada força adquire nesta relação. "A vontade de poder é o elemento do qual decorrem, ao mesmo tempo, a diferença de quantidade das forças postas em relação e a qualidade que, nessa relação, cabe a cada força." 85 O conceito de forças em Nietzsche subtende uma relação em que uma força é dominante enquanto outra, ou as demais são dominadas. A vontade é o elemento interno contido nessa relação que determina a dominação - sem que exista nela qualquer viés antropomórfico, ou mesmo divino. As forças relacionadas apresentam uma dupla gênese: "gênese recíproca de sua diferença de quantidade, gênese absoluta de sua qualidade respectiva." ${ }^{\text {" }}$ A vontade de potência por um lado determina a diferença de quantidade das forças, ou seja, determina sua condição de dominantes e dominadas; por outro vai determinar a qualidade das forças, e, assim, se são ativas ou reativas. “As forças são essencialmente diferenciadas e qualificadas. Exprimem sua diferença de quantidade pela qualidade que cabe a cada uma." ${ }^{~} 87$ A confusão e a dificuldade aparecem na tentativa de avaliação da qualidade da força que lhe dá sentido, mas é importante realçar que as designações ativo e reativo referem-se as qualidades originárias das forças, assim como dominante e dominado à suas relações primárias, e na vontade de potência o que se designa como qualidades primordiais são as de afirmação e negação. E, se toda ação é uma afirmação e toda reação é uma negação, e a vontade de potência se presentifica até mesmo no niilismo, é porque a afirmação é o

\footnotetext{
${ }^{82}$ TNR, p. 131

${ }^{83}$ Vontade de Poder ou Vontade de Potência referem-se à preferência dos tradutores nas línguas portuguesa e francesa não diferindo em seu significado ao conceito nietzscheano: Der Wille zur Macht.

${ }^{84} \mathrm{NF}$, p. 43

${ }^{85} \mathrm{NF}$, p. 41

${ }^{86} \mathrm{NF}, \mathrm{p} .42$

${ }^{87} \mathrm{NF}, \mathrm{p} .43$
} 
que dá o poder para a força se tornar ativa, bem como, a negação dota a força de seu poder reativo. Portanto, são o próprio devir ativo e devir reativo, ou seja, "como se a afirmação e a negação fossem ao mesmo tempo imanentes e transcendentes em relação à ação e a reação." 88 . Daí poderia advir à ideia que a vontade de potência impediria o acaso e o fortuito nas relações, pois se a vontade de potência é seu elemento interno de determinação é ela também quem influência e avalia a condição da ação ou da reação, mas...

A vontade de poder é o elemento genético da força, isto é, o elemento de produção de qualidade que cabe a cada força nessa relação. A vontade de poder não suprime o acaso mas, ao contrário, implica-o porque sem ele, ela não teria nem plasticidade nem metamorfose. $\mathrm{O}$ acaso é o relacionamento das forças; a vontade de poder, o princípio determinante dessa relação. A vontade de poder acrescenta-se necessariamente às forças, mas só pode acrescentar-se a forças relacionadas pelo acaso. A vontade de poder compreende o acaso em seu coração, só ela é capaz de afirmar todo o acaso. (DELEUZE; Nietzsche $e$ a filosofia, p.43)

A vontade de potência é determinada ao mesmo tempo em que determina, pois determina a relação de forças que se dá entre elas, como em um duplo de si mesma. E, assim, aparece com o poder de se afetar por si própria. Essa afetividade não significa passividade, mas a "forma afetiva primitiva", um pathos.

A relação das forças é determinada em cada caso na medida que uma força é afetada por outras, inferiores ou superiores. Daí se segue que a vontade de poder manifesta-se como um poder de ser afetado. Esse poder não é uma possibilidade abstrata, é preenchido e efetuado a cada instante pelas outras forças com as quais está em relação. (DELEUZE; Nietzsche $e a$ filosofia, p.50)

${ }^{88} \mathrm{NF}, \mathrm{p} .44$ 
As afecções de uma força são ativas na medida que ela se apodera daquilo que lhe opõe resistência, na medida que se faz obedecer por forças inferiores. Inversamente elas são sofridas, ou melhor acionadas, quando a força é afetada por forças superiores as quais obedece. Obedecer é, ainda, aí, uma manifestação da vontade de poder. (DELEUZE; Nietzsche e a filosofia, p.51)

Qualquer corpo é um fenômeno múltiplo, uma pluralidade de forças irredutíveis que se encontram em luta constante. "mas, na verdade, a dinâmica das forças nos conduz a uma conclusão desoladora. Quando a força reativa separa a força ativa do que ela pode, está última, torna-se, por sua vez, reativa." ${ }^{89}$ Este procedimento, que é uma condição própria do homem, é o que leva a dupla interpretação do eterno retorno: o conteúdo latente do eterno retorno é aquele submetido ao devir ativo, que implica a inserção imediata na potência da vontade de afirmação das forças ativas; porém, mediadas por uma vontade negativa, tornam-se forças reativas - o devir reativo na fala de Zaratustra: "Eternamente retorna o homem de que estás cansado, o pequeno homem [...] E eterno retorno também do menor! era este o fastio que eu sentia de toda a existência! Ah! nojo, Nojo, Nojo!"90

Daí, a defesa do conteúdo latente do eterno retorno como sentido primaz dado por Nietzsche, mesmo sem tê-lo formulado explicitamente, pois nele se apresenta uma seletividade que estabelece uma regra prática para eliminar da vontade as forças reativas menos desenvolvidas - pois em sua multiplicidade o somatório da negação torna-se superior à afirmação; eliminando, assim, os semiquereres, as meias vontades, restabelecendo sua integridade; para que o sentido de uma vontade afirmativa venha trazer no devir ativo o eterno retorno como elemento de criação. É assim que o eterno retorno se configura como o ápice da crítica à filosofia da representação, pois não se coloca como elemento de duplicação de um estado de ser ou de semelhança, mas ele mesmo, produzido e produtor de diferenças.

\footnotetext{
${ }^{89} \mathrm{NF}, \mathrm{p} .52$

${ }^{90}$ AFZ, p.261 - "O convalescente"
} 


\section{Conhecimento e Representação}

\subsection{Gênese}

Origem em filosofia é sempre difícil. Falar em um começo pressupõe um marco civilizatório qualquer onde uma condição moral foi estabelecida e, assim, está já condicionado aos pressupostos cognitivos ali constituídos. Mesmo uma origem histórica não escapa a esse princípio. E esses pressupostos morais estão condicionados nas ações e práticas cotidianas - senso comum - que possibilitam o pensamento e vêm possibilitar o que ficou convencionado como construção do conhecimento. Em filosofia não é diferente. A filosofia, como qualquer área do conhecimento, se serve, precisa se servir, dos modelos do senso comum para construir seus enunciados, pois, todo referencial para explanação, apresentação, demonstração ou comparação de uma ideia ou conceito tem sua origem naqueles pressupostos morais do senso comum.

Para Deleuze a relevância do problema da origem em filosofia traz a questão dos enunciados filosóficos que pressupõem conceitos previamente assimilados e que sejam indubitáveis para todos ${ }^{91}$. Pois, se na ciência os pressupostos são eminentemente objetivos e, por isso, podem ser eliminados com a confecção rigorosa de axiomas, na filosofia os pressupostos têm caráter tanto objetivo como subjetivo.

${ }^{91}$ DR, p. 189 
Os pressupostos objetivos em filosofia se dão como formas conceituais explicitamente supostos a partir de um conceito dado. Assim, por exemplo, quando Descartes não quer definir o homem como animal racional é porque pressuporia os conceitos de animal e de racional como explicitamente conhecidos ${ }^{92}$. Já, apresentando o Cogito como definição, Descartes procura superar os pressupostos objetivos que sobrecarregam os procedimentos que operam por gênero e diferença ${ }^{93}$. Mas, ainda assim, não evita a submissão aos pressupostos subjetivos que impõem implicitamente o assentimento a um sentimento ao invés de a um conceito. E mesmo, tendo a Filosofia origem em pressupostos subjetivos e enunciados implícitos, essa origem está sempre ligada a representações oriundas no senso comum, no não filosófico, na falsa inocência de uma ligação essencial que transforma a diferença em um retornar a si mesma... uma repetição. Dessa forma, busca-se encontrar com o conceito o que já era conhecido sem ele, ou seja, encontrar no fim o que já estava dado desde o começo. "[...] No caso da Filosofia, a imagem do círculo daria testemunho, antes de tudo, de uma impotência para começar verdadeiramente e para repetir autenticamente" 94 .

A conceituação, nos lembra Bergson em seu artigo de 1903, intitulado Introdução à Metafísica ${ }^{95}$, está necessariamente restrita a experiência de seu formulador, pois às faculdades de abstração, generalização e raciocínio estão diretamente ligadas à capacidade individual de quem as aplica. Além disso, todo conceito se constitui por uma descrição negativa de uma idéia colmatada na percepção a partir de uma intuição. Pois, na tentativa de apresentar essa idéia a outrem, como conceito, o filósofo precisa recortá-la de um todo que se estabeleceu mais como uma sensação que uma definição, para, através de análises e comparações, dizer aquilo que ela não é, e, assim, por redução, se aproximar de sua formatação original.

\footnotetext{
92 Idem

93 Ibid

${ }^{94}$ DR, p.192

${ }^{95}$ in; PM, p.183-234
} 
Logo, pelos conceitos alcançamos do objeto, apenas o que é comum a esse objeto, ou seja, aquilo que este simboliza; buscando a semelhança deste símbolo com a de outros objetos, convergindo às propriedades. E assim, os recompomos a partir de uma justaposição de conceitos que em verdade só nos apresenta um equivalente intelectual deles. Além disso, "o conceito generaliza ao mesmo tempo em que abstrai" "96; pois as propriedades que nele se ressaltam são comparáveis às de outros conceitos com os quais se assemelha. Simboliza uma propriedade comum em uma diversidade de coisas diferentes. Essa propriedade quando reinserida no objeto original coincide com ele; já extraída dele, expande-se indefinidamente para que, além dele, possa coincidir com outros objetos representados no conceito. Assim, os diversos conceitos formulados a partir das propriedades de uma coisa, ao alargarem-se, se integram com os de outras coisas sem se aplicar exatamente a nenhuma delas. Para retornar de onde partimos seria preciso escolher um desses conceitos, para com ele buscar os outros. Porém, devido à diversidade em questão, a escolha passa a influenciar o caminho da volta e, portanto, passamos a conceber diversamente a unidade múltipla da duração caso partamos da multiplicidade ou da unidade.

O cogito como gênese reflete este modelo, pois exprime a unidade das faculdades no sujeito, fazendo com que essas faculdades possam se referir a uma forma objeto a partir de uma identidade subjetiva, ou seja, uma reconstrução conceitual. Dando, assim, um conceito filosófico a um pressuposto do senso comum. "O eu puro do Eu penso é, portanto, uma aparência de começo apenas porque remeteu todos os seus pressupostos ao eu empírico"97. Quando afirmo: Eu penso; está implícito na afirmação: todo mundo sabe o que é Eu e o que é pensar; “...Todo mundo sabe, ninguém pode negar, é a forma da representação e o discurso do representante."98

\subsection{Recognição}

\footnotetext{
${ }^{96}$ PM, p.194

${ }^{97}$ DR, p. 189

${ }^{98}$ DR, p. 190
} 
O modelo da recognição é definido por Deleuze como o "exercício concordante de todas as faculdades sobre um objeto suposto como sendo o mesmo: é o mesmo objeto que pode ser visto, tocado, lembrado, imaginado, concebido..." ${ }^{99}$ Esse objeto será reconhecido através de uma faculdade (sentir, lembrar, imaginar, pensar...), a partir de uma identidade formada no conjunto das faculdades, por ela, e a elas referido. $\mathrm{Ou}$ seja, a recognição exige uma disposição prévia das faculdades como princípio subjetivo, senso comum, e, ainda, à unidade do sujeito pensante como fundamento sobre a forma de identidade do objeto, donde às outras faculdades figuram como seu modo. E é neste sentido que o cogito cartesiano se expressa como origem, pois "exprime a possibilidade de todas as faculdades se referirem a uma forma objeto que reflita a identidade subjetiva." ${ }^{100}$ Portanto, concedendo ao elemento do senso comum uma pretensão conceitual filosófica. Tanto em Kant como em descartes, o Mesmo elemento de recognição - é o objeto fundado no acordo das faculdades através da identidade do $\mathrm{Eu}$ no $\mathrm{Eu}$ penso. E, o que vai determinar esse acordo entre as faculdades é a outra face do senso comum: o bom senso. Como instâncias complementares o bom senso e o senso comum constituem as duas metades da doxa; o senso comum é a norma de identidade sob o ponto de vista do Eu puro e da forma objeto qualquer que lhe corresponde; o bom senso, do ponto de vista dos eus empíricos e dos objetos qualificados, é a norma de partilha. Quando o senso comum traz a forma do Mesmo, é o bom senso que determina, em cada caso, a contribuição das faculdades. Assim, a representação deriva, como forma, do modelo da recognição oriundo na imagem de um pensamento reto (ortodoxo) que sabe o que significa pensar, pois não é uma faculdade, mas, referido, como está, a um sujeito, é a unidade de todas as faculdades por ele orientadas em seus modos sob a forma do Mesmo. E tanto faz Platão, Descartes ou Kant, pois é a subordinação a este modelo que orienta o que significa pensar à análise filosófica.

\footnotetext{
${ }^{99}$ DR, p. 194
}

${ }^{100}$ DR, p. 195 
Tal orientação é deplorável para a Filosofia, pois o triplo nível suposto de um pensamento naturalmente reto, de um senso comum natural de direito, de uma recognição como modelo transcendental, só pode constituir um ideal de ortodoxia. (DELEUZE; Diferença e repetição, p.196)

Assim a Filosofia fica alijada de seu projeto de romper com a doxa. É bem verdade que, ainda assim, ela recusa toda doxa particular, evitando as proposições particulares do bom senso e do senso comum, mas mantém o essencial: a forma do senso comum, o elemento da recognição e o modelo de concordância das faculdades, tido como universal, fundado no sujeito pensante. "A imagem do pensamento é apenas a figura sob a qual universaliza-se a doxa, elevando-a ao nível racional," ${ }^{101}$ sem com isso nos desprendermos dela - doxa. O modelo da recognição, portanto, nunca elevou o pensamento senão ao reconhecível e o reconhecido mantendo-o numa espécie de zona de conforto do ato de pensar onde não há espaço para o surgimento do novo.

Considere-se o exemplo de Kant: de todos os filósofos, Kant foi o que descobriu o prodigioso domínio do transcendental. Ele é o análogo de um grande explorador; não um outro mundo, mas montanha ou subterrâneo desta mundo. Entretanto, que fez ele? Na primeira edição da Crítica da razão pura, ele descreve em detalhes três sínteses que medem a contribuição respectiva das faculdades pensantes, culminando todas na terceira, a da recognição, que se exprime na forma do objeto qualquer como correlato do $E u$ penso, ao qual todas as faculdades se reportam. É claro, assim, que Kant decalca as estruturas ditas transcendentais sobre os atos empíricos de uma consciência psicológica: a síntese transcendental da apreensão é diretamente induzida de uma apreensão empírica etc. É para ocultar um procedimento tão visível que Kant suprime este texto na segunda edição. Mais bem ocultado, o método do decalque, todavia, não deixa de subsistir, com todo o seu "psicologismo". (DELEUZE; Diferença e repetição, p.197)

${ }^{101}$ DR, p. 196 
Se por um lado é evidente que os atos de recognição se associam a nossa vida prática possibilitando o reconhecimento dos objetos cotidianos e suas qualidades, além de propiciar que reconheçamos estímulos e sentimentos que nos preparam para uma reação ou ação reflexa, o que em última análise, contribui para a manutenção da vida. Por outro, "a forma transcendental de uma faculdade confunde-se com seu exercício disjunto, superior ou transcendente" ${ }^{102}$. A forma transcendental de uma faculdade não é discernível a partir do uso de elementos comuns a outras faculdades, essenciais ou por aquilo que não é apreendido através da experiência sensível, pois transcendente não significa fora do mundo. $\mathrm{O}$ exercício transcendente, portanto, nem está coligado ao exercício empírico, nem situado em um além-mundo qualquer como as reminiscências platônicas. Isso, porque ele apreende, do exercício empírico, o que não pode ser apreendido do ponto de vista de um senso comum. Por essa razão a doutrina das faculdades, em Kant, caiu em descrédito, pois o transcendental não pode estar submetido na determinação do senso comum às formas empíricas ordinárias, tal como estas aparecem, a custa de não serem mais que um simulacro do transcendental sobre o empírico. Por isso o transcendental tem de estar sujeito a um empirismo superior em que cada faculdade será levada ao ponto extremo de seu desregramento, ponto em que se vê forçada a uma violência que a obriga a exercer a si mesma, violência daquilo que ela é forçada a apreender e daquilo que só ela tem o poder de apreender $^{103}$, e que, ainda, também, é o inapreensível.

Tríplice limite da última potência. Cada faculdade descobre, então, a paixão que lhe é própria, isto é, sua diferença radical e sua eterna repetição, seu elemento diferencial e repetidor, como o engendramento instantâneo de seu ato e o eterno reexame de seu objeto, sua maneira de nascer já repetindo. (DELEUZE; Diferença e repetição, p.208)

\subsection{Teoria Diferencial das Faculdades}

\footnotetext{
${ }^{102}$ DR, p.207
}

${ }^{103}$ DR, p.208 
Há nas percepções, certas coisas que não convidam o pensamento a um exame, porque a percepção basta para determiná-las, e há outras que o levam inteiramente a este exame, na medida em que a percepção nada fornece de sadio. (PLATÃO; $A$ República, VII, 523 b)

Platão distingue duas formas de pensamento: aquelas que deixam o pensamento tranquilo (método da recognição), e aquelas que forçam o pensamento pensar. No primeiro caso o pensamento encontra, junto a todas as suas faculdades, a imagem de si mesmo; e, reconhece nela as coisas nas quais associa o conteúdo de um entendimento prévio. Daí a pertinência da dúvida apresentada por Glauco a Sócrates: “será quando não se reconhece, quando se tem dificuldade em reconhecer, que se pensa verdadeiramente?"104; questão que será amplificada por Descartes levando ao ceticismo extremado da dúvida hiperbólica. Ainda assim, o pensamento não é forçado a pensar; pois, a dúvida pressupõe uma boa vontade do pensador e uma boa natureza do pensamento como ideal de recognição, atribuindo ao reconhecido uma afinidade com o verdadeiro, e assim, ao mesmo tempo, à "imagem do pensamento e o conceito de Filosofia." 105 Mesmo quando fazemos relações entre um objeto que ao mesmo tempo seja empírico e do conhecimento, um triangulo por exemplo, e estabelecemos a relação de sua imagem com sua formulação geométrica (a soma de seus três ângulos é igual a $180^{\circ}$ ), ainda assim poderíamos pensar neste mesmo triangulo sem pensar em sua relação matemática, como Descartes assim observou. Pois, aquilo que leva o pensamento a encontrar seu duplo, leva-o a uma espécie de zona de conforto onde encontra seu análogo, algo que ele reconhece como ele próprio, isso não o levará a pensar de modo algum já que nele o questionamento suposto se apresenta como uma verdade previamente estabelecida. A necessidade de pensar não pode ser colocada no próprio pensamento ela precisa ser instada a partir de um encontro que a estimule, que a dobre a este fim, que a force mesmo a contragosto, enfim que a

\footnotetext{
${ }^{104}$ DR, p.202

105 Idem
} 
obrigue, estabelecendo assim uma "necessidade absoluta de um ato de pensar" encontro fundamental ,que vai recusar o modelo de recognição.

$\mathrm{Na}$ verdade, os conceitos designam tão somente possibilidades. Falta-lhes uma garra, que seria a da necessidade absoluta, isto é, de uma violência original feita ao pensamento, de uma estranheza, de uma inimizade, a única a tirá-lo de seu estupor natural ou de sua eterna possibilidade: tanto quanto só há pensamento involuntário, suscitado, coagido no pensamento, com mais forte razão é absolutamente necessário que ele nasça, por arrombamento, do fortuito no mundo. O que é primeiro no pensamento é o arrombamento, a violência, é o inimigo, e nada supõe a Filosofia; tudo parte de uma misosofia. (DELEUZE; Diferença e repetição, p.202-203)

Esse encontro fundamental vem a ser apreendido através de "tonalidades afetivas", e, como tal, afeta nossos sentidos de uma forma imediata. Esses objetos dados de imediato à sensibilidade não são qualitativos ou quantitativos, mas semióticos, signos. Na recognição aquilo que se relaciona com os sentidos não é reconhecido senão após a mediação que o liga com o que pode ser "lembrado, imaginado ou concebido" 107 , subordinando-o às faculdades e o transformando a partir do exercício delas sobre ele em senso comum. Já a partir da imediatez do encontro o objeto perde a condição - na verdade deixa de se estabelecer como tal - de ser sensível, passando ao próprio ser do sensível. "Não é o dado, mas aquilo pelo qual o dado é dado."108 Além disso o ser do sensível (sentiendum) força a alma a um problema: como reconhecer aquilo que não pode ser reconhecido, pois não encontra seu duplo na memória, pois não o tem circunscrito em um passado acessível? Platão vai ligar essa questão a um passado imemorial, apelando a um memorandum - ser da memória que separa a memória empírica de outra que em última instancia vai se reportar ao ser do passado: a memória transcendental, portadora das reminiscências. A memória empírica é a memória do mundo sensível, portanto, ativada pelos sentidos, pela

\footnotetext{
${ }^{106}$ DR, p.203

${ }^{107}$ DR, p.203

${ }^{108}$ Idem
} 
imaginação ou pelo pensamento. "O esquecido no sentido empírico é o que não se chega a apreender novamente pela memória quando procuramos uma segunda vez (está muito longe, o esquecido me separa da lembrança ou a apagou)."109 A memória transcendental, ao contrário, concerne àquilo que sempre só poderia ser lembrado, mas que fora esquecido desde o início. O mesmo sendo aplicado a sensibilidade que vai opor o exercício empírico dos sentidos a um insensível essencial, "que se confunde com aquilo que só pode ser sentido do ponto de vista do exercício transcendente." 110 Assim, o sentiendum obriga a sensibilidade forçar a memória a recordar-se do memorandum. E, por fim, a memória transcendental "força o pensamento a apreender aquilo que só pode ser pensado, o cogitandum, o noetéon, a Essência""111.

Do sentiendum ao cogitandum se desenvolveu a violência daquilo que força a pensar. Cada faculdade saiu dos eixos. Mas o que são os eixos a não ser a forma do senso comum que fazia que todas as faculdades girassem e convergissem? Cada uma, por sua conta e em sua ordem, destruiu a forma do senso comum, forma que mantinha no elemento empírico da doxa, para atingir a sua enésima potência, como ao elemento do paradoxo no exercício transcendente. Em vez de todas as faculdades convergirem e contribuírem para o esforço comum de reconhecer um objeto, assiste-se a um esforço divergente, sendo cada uma colocada em presença do seu "próprio", daquilo que a concerne essencialmente. (DELEUZE; Diferença $e$ repetição, p.205)

\title{
3.4 A Reversão de Immanuel Kant
}

\author{
"O tempo está fora dos gonzos..."112 \\ Shakespeare, Hamlet, 1, 5
}

\footnotetext{
${ }^{109}$ DR, p.204

${ }^{110}$ DR, p. 205

${ }^{111}$ Idem

112 “The time is out of joint...”; CC, p.40
} 
O tempo circula sobre um eixo que o subordina aos movimentos dos períodos por ele medidos, assim como uma porta gira sobre o gonzo. Dessa forma Deleuze, no artigo "Sobre Quatro Fórmulas Poéticas Que Poderiam Resumir A Filosofia Kantiana"113, apresenta a ideia antiga de tempo circular, aquele determinável, que submetido ao movimento extensivo, era usado para medir os movimentos orbitais e climáticos confrontando-o com a fórmula de Shakespeare, pois enquanto estiver no eixo o tempo estará subordinado a movimentos no espaço.

Essa concepção de tempo, cara a filosofia antiga, o submetia a um retornar sempre ao mesmo, garantido pelo ser do divino, que o mantinha dependente do movimento e da proximidade com o eterno, por necessidade de uniformidade e perfeição. Mas, quando o tempo mede a si mesmo, ou seja, a sua própria temporalidade nos movimentos terrestres aberrantes e derivados ${ }^{114}$ demonstra uma tendência a se emancipar; apesar de manter-se ainda subjugado ao movimento naquilo que o origina e deriva.

O tempo out of joint, a porta fora dos gonzos, significa a primeira grande reversão kantiana: é o movimento que se subordina ao tempo. O tempo já não se reporta ao movimento que ele mede, mas o movimento ao tempo que o condiciona. (DELEUZE; Crítica $e$ Clínica, p.41)

Foi em Kant que a passagem da ideia de um tempo cardinal - que, ligado aos pontos cardeais, o sujeitava ao movimento do mundo - para um tempo ordinal - onde os acontecimentos que lhe davam conteúdo é que passam a subordinados dele - se consolidou. "Ao não mais curvar-se ao movimento que ele antes media, no mesmo gesto se emancipa da eternidade que servia de modelo a esse mesmo movimento."115 Sua emancipação o libera de qualquer instancia que o subordine, seja metafísica ou

${ }^{113} \mathrm{CC}, \mathrm{p} .40$

${ }^{114} \mathrm{CC}, \mathrm{p} .41$

115 TNR, p.153 
transcendente. Assim, apesar de o tempo conter tudo o que se move e se transforma, ele mesmo não o faz. Ele é a forma daquilo que se move e transforma, porém, nele mesmo, uma forma imutável. "Não uma forma eterna, mas justamente a forma daquilo que não é eterno, a forma imutável da mudança e do movimento."116

A primeira reversão kantiana retifica o tempo retirando dele a submissão ao movimento cósmico originário ou ao movimento meteorológico derivado, pois o tempo não está relacionado a um objeto, mas ao espaço como condição do ato à que o movimento está condicionado. O tempo não é mais um círculo, agora é uma linha reta, inexorável. E, portanto, deixa de ser subordinado a uma divindade que o mantinha dependente do movimento, para, por si mesmo e em si mesmo, impor "a todo movimento possível à sucessão de suas determinações". ${ }^{117}$

Já não se trata de definir o tempo pela sucessão, nem o espaço pela simultaneidade, nem a permanência pela eternidade. Permanência, sucessão e simultaneidade são modos ou relações de tempo (duração, série, conjunto). São as cintilações do tempo. (DELEUZE; Crítica e Clínica, p.42)

Assim, não cabe mais, a partir de Kant, definir o tempo como sucessão, pois se assim fosse ele teria que suceder a si mesmo até o infinito, mas as coisas se sucedem diversamente, assim como são simultâneas ao mesmo tempo. Portanto, tanto o tempo quanto o espaço passam a ter novas determinações constitutivas em que a autonomia de cada um vem substituir a hierarquia do movimento.

"Eu é um outro..."

Rimbaud, carta a Izambart, maio de 1871, $1871^{118}$

Carta a Demeny, 15 de maio de

${ }^{116}$ CC, p.42
${ }_{117}$ CC, p.41
${ }^{118}$ CC, p.42 
"Havia outra concepção antiga do tempo, como modo do pensamento ou movimento intensivo da alma: uma espécie de tempo espiritual e monacal". ${ }^{119}$

O cogito cartesiano vai laicizar a ideia de tempo como movimento da alma, ou seja, um sentir do tempo como estado interno do ser vivente, com sua fórmula: "Penso logo sou!"; nela a determinação do pensar implica uma indeterminação do ser. Quando Descartes concebe sua primeira certeza indubitável ele fratura a concepção antiga de existência una, para outra, dual, onde aparece um movimento interno daquele que vem a conhecer aquele que existe para ser conhecido - que é a condição de possibilidade para uma substância pensante postular sua existência. Logo, ser um sujeito que se reconhece pensante implica em uma consciência de si - um existente anterior a ela - que por outro lado só pode ser reconhecido como existente por essa consciência.

[...] o eu penso é um ato de determinação instantânea, que implica uma existência indeterminada (eu sou) e que a determina como a de uma substancia pensante (eu sou uma coisa que pensa). Mas como a determinação poderia incidir sobre o indeterminado se não se diz de que maneira ele é "determinável”? Ora, esse protesto kantiano não deixa outra saída: é somente no tempo, sob a forma do tempo, que a existência indeterminada torna-se determinável. (DELEUZE; Crítica e Clínica, p.42-43)

"Assim o eu penso afeta o tempo e apresenta a cada instante um grau de consciência". ${ }^{120}$ E é a produção intensiva desse grau de consciência no instante que vai determinar no tempo o movimento Eu-Eu. Kant foi o primeiro a apresentar o tempo como instância possível para o movimento duplo do " $E u$ " - consciente e existente - operando, assim, uma segunda emancipação do tempo, completando sua laicidade $^{121}$.

\footnotetext{
${ }^{119}$ Idem

${ }^{120} \mathrm{CC}, \mathrm{p} .43$

${ }^{121}$ Idem
} 
A formula de Rimbaud "je est um autre", posibilita a Deleuze um desdobramento mais detalhado da questão kantiana: O Eu (Moi) e o $\boldsymbol{E u}$ (Je) estão separados, no tempo, em um movimento contínuo de afeto mútuo condicionado por uma diferença fundamental, pois minha existência "Eu", por mais que mude, é passiva e se representa em sua forma de determinação espontânea: o $E u$, que a afeta como se fora um Outro (paradoxo do sentido intimo). ${ }^{122}$ A representação do Eu aparece como forma determinada a partir de um Outro, que por um lado afasta o Eu do $E u$ no tempo, e por outro promove uma atualização onde o $E u$ é a determinação para que o Eu possa se determinar.

O Eu [Moi] está no tempo e não para de mudar: é um eu passivo, ou antes, receptivo, que experimenta as mudanças no tempo. O Eu [Je] é um ato (eu penso) que determina ativamente minha existência (eu sou), mas só pode determiná-la no tempo, como a existência de um eu [moi] passivo, receptivo e cambiante que representa para si tão somente a atividade de seu próprio pensamento. (DELEUZE, Crítica e Clínica, p.43)

Apesar da separação do $E u$ ao Eu, sou Um! Essa é a loucura que remete o sujeito ao tempo fora dos gonzos. Separação no tempo que junta, costura, funde o $E u$ com o Eu ao operar sua síntese no instante. Dessa forma, Kant ultrapassou Rimbaud, uma vez que superou o modelo aristotélico conceito-objeto, onde o primeiro é uma forma ato e o segundo uma forma potência, em sua materialidade. Pois, fez do $E u$ a representação conjugada ao conceito, e do Eu "aquilo a que todos os objetos se reportam como à variação contínua de seus próprios estados sucessivos e à modulação infinita de seus graus no instante"123. E apesar da relação conceito-objeto subsistir em Kant, ela agora "encontra-se duplicada pela relação $E u$-Eu, que constitui uma modulação, não

\footnotetext{
122 Ibid

${ }^{123}$ CC, p.44
} 
mais uma moldagem"124. E assim, a distinção das formas como conceitos, ou das matérias como objetos, passa a um escoar, um fluir linear em sentido único, substituindo-as em novas relações formais e de um novo material. É o fio do tempo. $^{125}$

Enfim, se é a partir do $E u$ que nossa existência pode ser determinada como a de um eu passivo que muda no tempo, é só no formalismo do tempo que o espírito pode ser auto afetado, e, então, deve ser apresentado como a relação formal pela qual interiormente nos afetamos por nós mesmos. Por isso, o tempo, como forma imutável, não pode ser definido como sucessão de instantes, e o espaço não pode ser definido pela simultaneidade de existências, mas como formas de interioridade e exterioridade - relações formais estabelecidas entre o Eu (Moi) e o $E u(\mathrm{Je})$, que vem a tornar possível que eu me represente e possa representar os objetos como outros.

A interioridade não para de nos escavar a nós mesmos, de nos cindir a nós mesmos, de nos duplicar, ainda que nossa unidade permaneça. Uma duplicação que não vai até o fim, pois o tempo não tem fim, mas uma vertigem, uma oscilação que constitui o tempo, assim como um deslizamento, uma flutuação constitui o espaço ilimitado. (DELEUZE, Crítica e Clínica, p.45)

A terceira reversão se dá no campo da moral, ou no estabelecimento de modelos de coerção para o estabelecimento de caminho seguro em busca do Bem. "A consciência antiga fala das leis porque elas nos fazem conhecer o Bem, ou o melhor em tais ou quais condições: as leis dizem o que é o Bem do qual elas decorrem."126

\footnotetext{
${ }^{124}$ Idem

125 Roberto Machado vai avaliar, em Deleuze - A arte e a filosofia, que a critica kantiana vem negar um encadeamento suficiente entre os dois termos, apresentando um terceiro termo que será o responsável a fazer da lógica uma instancia transcendental, e, com isso, constituir uma diferença entre a determinação e o que ela determina, a qual Deleuze identifica como a descoberta da diferença transcendental. Como se "por um instante Kant tivesse vislumbrado a ameaça de um jogo imanente, sem regras, para em seguida opor-lhe seu chão critico". (TNR, p.157)

${ }^{126}$ CC, p.45
} 
"Que suplício ser governado por leis que não se conhece!...Pois o caráter das leis tem necessidade assim do segredo sobre seu conteúdo..."

Kafka, A muralha da China ${ }^{127}$

Os argumentos contraditórios nas fórmulas expostas dos antigos e de Kafka demonstram a reversão promovida por Kant a partir da Critica da Razão Prática entre o Bem e a lei submetendo o primeiro à segunda: “o que diz a lei está bem, é o bem que depende da lei." ${ }^{128}$ A pergunta se desloca do, que preciso fazer? para, como devo agir? A partir daí uma ação será considerada moral se puder ser pensada sem contradição como universalmente válida. "A lei se define, portanto, como pura forma de universalidade. Não nos diz qual objeto a vontade deve perseguir para ser boa, mas qual forma deve tomar para ser moral." ${ }^{129}$ O critério de balizamento de uma ação deixa de ser o certo-errado e passa ao que avalia a ação como válida ou inválida. Assim na lei não há conteúdos, já que qualquer conteúdo a identificaria a um Bem, em que ela seria, então, apenas sua cópia. Como ela se inscreve em nós com seu lema: Age por dever; não comunica nossas faltas nem apresenta um objetivo fim a ser conquistado é, portanto, mais severa quanto nos empenhamos a cumpri-la. "Freud mostrou que se o dever, nesse sentido, supõe uma renuncia aos interesses e inclinações, a lei se exercerá com tanto mais força e rigor quanto mais profunda for a nossa renuncia." ${ }^{130}$ Daí a consciência moral fica mais forte exigindo renuncias maiores, renuncia sem limites, renuncia à vida. "esse caminho que excede os limites de nossa vida e requer a imortalidade da alma, segue a linha reta do tempo inexorável e incessante na qual permanecemos em contato constante com a lei."131

Quando o tempo sai dos gonzos, temos que renunciar ao ciclo antigo das faltas e expiações para seguir a estrada infinita da morte lenta, do juízo prorrogado ou da divida infinita. O tempo não nos deixa outra alternativa jurídica senão Kafka em $O$ processo: ou a

${ }^{127}$ Kafka, A muralha da China; apud DELEUZE, Crítica e Clínica, p.45

${ }^{128} \mathrm{CC}$, p.46

${ }^{129}$ Idem

${ }^{130}$ CC, p.46

${ }^{131}$ CC, p. 47 
absolvição aparente ou a moratória ilimitada. (DELEUZE, Crítica e Clínica, p.47)

"Chegar ao desconhecido pelo desregramento de todos os sentidos [...] um longo, imenso e raciocinado desregramento de todos os sentidos."

Rimbaud, idem ${ }^{132}$

A quarta reversão kantiana aparece na terceira Crítica - do juízo; no movimento interconectado de todas as faculdades. Se nas duas primeiras críticas havia sempre uma faculdade dominante - o entendimento na Critica da razão pura $\mathrm{e}$ a razão na Critica da razão prática - fazendo de todas as outras coadjuvantes, na Crítica da faculdade judicativa as faculdades fazem um acordo mútuo, sem que haja prevalência de alguma sobre as demais. Nela o Belo será definido pelo modo como os fenômenos conferem "ao sentido intimo do tempo uma dimensão suplementar autônoma, à imaginação um poder de reflexão livre, ao entendimento uma potência conceitual infinita" ${ }^{133}$. O Sublime será o resultado de uma interação entre todas as faculdades, que as levam a seus limites conflitantes, para, daí, surgir uma relação "no mais profundo delas mesmas, no que de mais estranho elas têm." 134

Já não é a estética da Critica da razão pura, que considerava o sensível como qualidade reportável a um objeto no espaço e no tempo; não é uma lógica do sensível, nem sequer um novo logos que seria o tempo. É uma estética do Belo e do Sublime, onde o sensível vale por si mesmo e se desdobra num pathos para além de toda lógica, que apreenderá o tempo no seu jorro, indo até a origem de seu fio e de sua vertigem. Já não é o Afecto da Critica da razão pura, que reportava o $\mathrm{Eu}$ ao $E u$ numa relação ainda regulada segundo a ordem do tempo, e sim um Pathos que os deixa evoluir livremente para formar estranhas combinações enquanto fontes do tempo, "formas arbitrárias de intuições possíveis". Já não é a determinação do Eu que deve juntar-se à determinabilidade do Eu para construir o conhecimento, agora é a unidade

\footnotetext{
${ }^{132}$ CC, p.47

${ }^{133}$ CC, p.49

${ }^{134}$ Idem
} 
indeterminada de todas as faculdades (Alma) que nos faz entrar no desconhecido. (DELEUZE, Crítica $e$ Clínica, p.48)

Deleuze ressalta na evolução livre do exercício divergente na Critica da faculdade judicativa, uma dissonância, um acordo/acorde discordante que é a grande descoberta da terceira Crítica. "A emancipação do tempo deve ser colocada sob a luz da emancipação da diferença, e este conjunto anuncia precisamente o tempo como Círculo da Diferença, como Círculo do Outro." "135

\subsection{A Diferença em Bergson}

Uma filosofia da diferença tem como primeira tarefa determinar as diferenças de natureza entre as coisas, para que assim, possa voltar às próprias coisas como elas mesmas. Mas também ainda, sua ontologia se apresenta através de suas diferenças de natureza, portanto, "podemos esperar que a própria diferença seja alguma coisa". ${ }^{136}$ Assim nos colocamos diante de dois problemas que se autorreferenciam, o primeiro de ordem metodológica, e o segundo de ordem ontológica: "o problema das diferenças de natureza e o da natureza das diferenças". ${ }^{137}$ Daí vem a crítica de Bérgson aos filósofos seus antecessores: por não utilizarem um rigor metodológico que os levassem a descobrir as verdadeiras diferenças de natureza, não as confundindo com diferenças de grau e vice-versa. Portanto,

se a filosofia tem uma relação positiva e direta com as coisas, isso somente ocorre à medida que ela pretende apreender a coisa mesma a partir daquilo que tal coisa é, em sua diferença a respeito de tudo aquilo que não é ela, ou seja, em sua diferença interna (DELEUZE; $A$ ilha deserta; p.47-48)

\footnotetext{
135 TNR, p. 162

136 ID, p.47

${ }^{137}$ Idem
} 
A questão da diferença interna se reflete, então, na diferença externa. Mas, se se faz uma redução por negação a uma delas, imediatamente também negamos a outra, ou caso identifiquemos diferenças de natureza entre indivíduos de um mesmo gênero, reconhecemos que ela não pode ser exclusivamente exterior, ou superior à coisa, e que não se localiza no espaço-tempo, ou que possa ser definida como diferença genérica ou específica.

Suponham que ao examinar os estados agrupados sob o nome de prazer nada se descubra neles de comum, a não ser o fato de serem estados que o homem procura: a humanidade terá classificado essas coisas num mesmo gênero porque encontrava nelas o mesmo interesse prático e reagia a todos do mesmo modo (BERGSON; o pensamento e o movente; p.55)

\begin{abstract}
Dessa forma, Bergson propõe à Filosofia um ideal metodológico que supere os elementos críticos e de generalização, que estabelecem apenas uma relação negativa com as coisas, demonstrando que é preciso partir das diferenças de natureza antes de partir à definição sobre a natureza da diferença como diferença interna da coisa. A proposta de Bergson é esculpir um conceito que se adapte ao objeto exclusivamente, um conceito que, de fato, nos dê do objeto o que ele é ao nos referirmos a ele. "Essa unidade da coisa e do conceito é a diferença interna, à qual nos elevamos pelas diferenças de natureza." ${ }^{138}$ Esse método, assim como proposto por Bergson, é a intuição.
\end{abstract}

“A intuição não é um sentimento nem uma inspiração, mas um método [...] dos mais elaborados métodos da filosofia. ${ }^{139} \mathrm{O}$ método consiste essencialmente na aplicação de regras em três etapas: "a primeira concerne à posição e a criação de problemas [denunciar os falsos problemas]; a segunda, a descoberta de verdadeiras diferenças de natureza [afastar a ilusão para reencontrar as verdadeiras articulações do real]; a

\footnotetext{
${ }^{138}$ ID, p.48
}

${ }^{139}$ B, p. 9 
terceira, à apreensão do tempo real [colocar e resolver os problemas em função do tempo mais do que do espaço]"140

Bergson explica que os falsos problemas surgem de uma confusão e de um preconceito, pois desde cedo aprendemos a nos debruçarmos sobre os problemas colocados por outrem, procurando solucioná-los; mas a verdadeira liberdade se encontra na "constituição dos próprios problemas"141, mais do que de sua solução, visto que a solução de um problema especulativo já estará contida em sua formulação. Mas um problema ao invés de desenvolvido deve ser inventado. Sua invenção, seja na matemática ou na metafísica, só pode ser dar quando os termos nos quais ele se dará assim estiverem postos. É necessário que a colocação de um problema tenha clareza em sua proposição, portanto ele só pode se dar quando o entorno de suas relações intrínsecas confluírem a ele. Assim, tanto a colocação quanto a solução dos verdadeiros grandes problemas se equivalem. Já os falsos problemas podem ser de dois tipos: os problemas inexistentes, aqueles em que seus termos implicam uma confusão; e, os problemas mal colocados, em que seus termos implicam mistos mal analisados; como no exemplo sobre o prazer, anteriormente apresentado. O exemplo clássico que Bergson apresenta no primeiro caso é o de que “a mais e não menos na ideia de não-ser do que na de ser; na desordem do que na ordem; no possível que no real." ${ }^{142}$ Porque a ideia negativa contém a ideia positiva e mais a própria negação dela, mais, ainda, o motivo dessa negação, portanto, reúne todo conteúdo real contido na ideia além das virtualidades contidas na contrafação.

Quando perguntamos "porque alguma coisa em vez de nada?", ou "porque ordem em vez de desordem?", ou "porque isto em vez de aquilo (aquilo que era igualmente possível)?", caímos em um mesmo vício: tomamos o mais pelo menos, fazemos como se o não ser preexistisse ao ser, a desordem à ordem, o possível à existência, como se o ser viesse preencher um vazio, como se a ordem viesse organizar uma desordem

\footnotetext{
${ }^{140} \mathrm{~B}, \mathrm{p} 10,11,16$ e 24

${ }^{141}$ B, p. 11

${ }^{142}$ B, p. 13
} 
prévia, como se o real viesse realizar uma possibilidade primeira. O ser, a ordem ou o existente são a própria verdade; porém no falso problema, há uma ilusão fundamental, um "movimento retrógrado do verdadeiro", graças ao qual supõe-se que o ser, a ordem e o existente precedam a si próprios ou precedam ao ato criador que os constitui, pois, nesse movimento, eles retroprojetam uma imagem de si mesmos em uma possibilidade, em uma desordem, em um não-ser supostamente primordiais. (DELEUZE; Bergsonismo; p.13)

Reencontrar as verdadeiras diferenças de natureza, "trata-se sempre, segundo Bergson, de dividir um misto segundo suas articulações naturais."143 Todo conhecimento empírico se dá através de mistos. As coisas que afetam nossa percepção sensível chegam a nós sempre misturadas. Bergson dá como exemplo a representação do tempo sempre penetrada pelo espaço. "O deplorável é que não sabemos distinguir em tal representação os dois elementos componentes que diferem por natureza, as duas puras presenças da duração e da extensão."144 Tratamos as misturas como se fossem uma unidade, e por isso, tratamos o impuro como se fosse puro. Mas só o que difere por natureza pode ser dito puro, e apenas tendências diferem por natureza.

Trata-se, portanto, de dividir o misto de acordo com tendências qualitativas e qualificadas, isto é, de acordo com a maneira pela qual o misto combina a duração e a extensão definidas como movimentos, direções de movimentos (como a duração-contração e a matériadistensão). (DELEUZE; Bergsonismo; p.17)

As críticas de Bergson vão se pautar aí, onde só se encontrou diferenças de grau em vez de diferenças de natureza. À metafísica, que estabeleceu uma eternidade primeira e dela derivou um tempo espacializado onde o tempo é a degradação, distensão ou diminuição do ser; à ciência, que também espacializou o tempo no qual os "seres só

\footnotetext{
${ }^{143}$ B, p. 17
}

${ }^{144}$ Idem 
apresentam diferenças de grau, de posição, de dimensão, de proporção." ${ }^{145}$ E por conta de tal confusão entre as diferenças de natureza e grau, os falsos problemas proliferam.

Colocar o problema e resolvê-lo mais em função do tempo do que do espaço, essa é a terceira etapa do método, mas também é o seu sentido fundamental, pois "a intuição supõe a duração" 146 A divisão mais fundamental do bergsonismo é entre a duração e o espaço; a duração carrega em si mesma o poder de variar qualitativamente; o espaço se dá em uma homogeneidade quantitativa. Logo, é a duração portadora de todas as diferenças de natureza e o espaço de todas as diferenças de grau.

\begin{abstract}
Consideremos um pedaço de açúcar: há uma configuração espacial, mas sob esse aspecto nós só apreendemos tão somente diferenças de grau entre esse açúcar e qualquer outra coisa. Contudo, há também uma duração, uma maneira de ser no tempo, que se revela pelo menos em parte no processo da dissolução, e que mostra como esse açúcar difere por natureza não só das outras coisas, mas primeiramente e sobretudo de si mesmo. Essa alteração se confunde com a essência ou a substancia de uma coisa; é ela que nós apreendemos, quando falamos de Duração. [...] "devo esperar que o açúcar dissolva" [...] Ela significa que minha própria duração, tal como eu a vivo, por exemplo, na impaciência das minhas esperas, serve de revelador para outras durações que pulsam com outros ritmos, que diferem por natureza da minha. (DELEUZE; Bergsonismo; p.26)
\end{abstract}

Bergson apresenta o tempo abstrato como um misto de espaço e duração. O espaço, por sua vez, é um misto de matéria e duração. A matéria é uma tendência e a duração é outra. Na primeira temos um afrouxamento, na segunda uma contração. Mas a diferença de natureza não se coloca entre as duas tendências, nem como o resultado da tensão entre elas, mas do lado da duração, e, portanto, como tendência se opõe a extensão. "A duração é o que difere de si, a matéria, ao contrário, é o que não diferi

\footnotetext{
${ }^{145}$ B, p. 18
}

${ }^{146} \mathrm{~B}, \mathrm{p} .25$ 
de si, é o que se repete. [...] O que difere tornou-se ele próprio uma coisa, uma substância." ${ }^{147}$ É por isso que no começo dissemos que a diferença de natureza é também uma coisa, pois "a duração é o que difere, e o que difere não é mais o que difere de outra coisa, mas o que difere de si. A duração é concebida como a diferença de natureza em si e por si, enquanto o espaço é a diferença de grau fora de si e para nós." ${ }^{148}$ A diferença de natureza, ela própria, deveio uma natureza. ${ }^{149}$

[...] em Matéria e memória: a duração, o indivisível, não é exatamente o que não se deixa dividir, mas o que muda de natureza ao dividir-se, e o que muda assim de natureza define o virtual ou o subjetivo. (DELEUZE; A ilha deserta, p.56)

Há uma grande semelhança entre o platonismo e o bergsonismo, pois ambos desenvolveram uma filosofia da diferença que não se reduz ao negativo e a contradição. Mas, apesar disso, em Platão há um princípio de finalidade, um telos, como regra de escolha, que subordina a diferença ao Bem. Em Bergson a diferença tornou-se a própria coisa, "não há mais lugar para dizer que a coisa recebe sua diferença de um fim."150 A diferenciação é produção de objetos; esses objetos encontram sua razão no conceito, pois o que se diferencia é antes de mais nada, o virtual. “Assim como as coisas se tornaram nuanças ou graus do conceito, o próprio conceito tornou-se a coisa." ${ }^{151}$ Mas já não há vários objetos para um mesmo conceito, e sim um conceito que se identifica com a coisa. $O$ conceito assim expresso não generaliza, nem universaliza o que ele designa, mas é a diferença em si dos objetos por ele relacionados; ele é a própria diferença interna. Então, "o que era preciso fazer para atingir esse objetivo filosófico superior? [...] Era preciso substituir as diferenças espaciais pelas diferenças temporais." 152

\footnotetext{
${ }^{147}$ ID, p.54

148 TNR, p.39

${ }^{149}$ TNR, p.55

${ }^{150}$ ID, p.59

${ }^{151}$ ID, p.61

${ }^{152}$ Idem
} 
Bergson vai buscar na biologia, em A evolução criadora, como o processo da diferenciação opera: "a vida é o processo da diferença," 153 porquanto não se reduz ao grau, à intensidade, à alteridade ou à contradição. Essa diferença, vital, é também uma diferença interna, mas, como tal, não pode ser confundida ou associada com uma determinação; pois, uma determinação precisa estar ligada ao acaso ou a uma causa, implicando uma exterioridade subsistente ${ }^{154}$. A diferença vital apresenta um caráter imprevisível, indeterminado, e, como nos diz Bergson, "não é o acidental, mas, ao contrário, o essencial, a negação do acidente." ${ }^{155} \mathrm{Na}$ verdade o impulso vital é causa sui, isso quer dizer que ela se diferencia de si mesma através, "sobretudo, da força explosiva que a vida traz em si." 156

Diferenciar-se é o movimento de uma virtualidade que se atualiza. A vida difere de si mesma, de tal modo que, também em cada linha acharemos certos aparelhos, certas estruturas de órgãos idênticos obtidos por meios diferentes. Divergência das séries, identidade de certos aparelhos, tal é o duplo movimento da vida como um todo. A noção de diferenciação traz ao mesmo tempo a simplicidade de um virtual, a divergência das séries nas quais ele se realiza e a semelhança de certos resultados fundamentais que ele produz nas séries. (DELEUZE; $A$ ilha deserta, p.57)

Impulso vital, diferença vital, diferenciação, diferenças temporais, diferença de natureza, duração. Quando a diferença torna-se sua própria substância após ter retirado os pressupostos e confusões que levam aos falsos problemas, e, ainda, a recognição, repetição e a representação; só então o novo surge como Vida.

Indeterminação, imprevisibilidade, contingência, liberdade significam sempre uma independência em relação às causas: é neste sentido que Bergson enaltece o impulso vital [...] $\mathrm{O}$ que ele quer dizer é que, de

\footnotetext{
${ }^{153}$ ID, p.56

${ }^{154}$ Aqui podemos aludir ao eixo/centro do círculo monocentrado da antiguidade.

${ }^{155} \mathrm{ID}, \mathrm{p} .57$

${ }^{156}$ Idem
} 
algum modo, a coisa vem antes de suas causas, que é preciso começar pela própria coisa, pois as causas vêm depois. Mas a indeterminação jamais significa que a coisa ou a ação teriam podido ser outras. "Poderia o ato ser outro?" é uma questão vazia de sentido. A exigência bergsoniana é a de levar a compreender por que a coisa é mais isso do que outra coisa. A diferença é que é explicativa da própria coisa, e não suas causas. [...] O bergsonismo é uma filosofia da diferença e da realização da diferença: há a diferença em pessoa, e esta se realiza como novidade. (DELEUZE; $A$ ilha deserta, p.71)

\subsection{Imanência e Campo Transcendental}

“Pode-se dizer da pura imanência que ela é UMA VIDA, e nada diferente disso". ${ }^{157}$

A imanência absoluta não existe em algo além dela mesma. Ela não está em relação de transcendência com um "Algo" superior a todas as coisas, ou "a um sujeito como ato que opera a síntese das coisas". ${ }^{158}$ Ela é, em termos espinozanos, uma beatitude completa, uma "consciência imediata absoluta, cuja atividade mesma não remete mais a um ser, embora não cesse de se situar em uma vida". ${ }^{159}$ Ela é uma potência completa.

Ele sabia, enfim, que estava em vias de adquirir um verdadeiro nome próprio, Homem dos Lobos, bem mais adequado que o seu, posto que acedia à mais alta singularidade na apreensão instantânea de uma multiplicidade genérica. (MP1, p.52; in, 1914 - Um só ou vários lobos?)

${ }^{157}$ DELEUZE; A imanência: uma vida...; Revista digital Educação e Realidade/UFRGS - vol. 27, $\mathrm{n}^{\circ} 2$ - 2002, p.10-18; tradução de Tomaz Tadeu do original "L'immanence: une vie...", in Philosophie, $\mathrm{n}^{\circ}$ 47, Minuit: Paris, 1995, p.3-7.

${ }^{158}$ Idem

${ }^{159}$ Ibidem, citando FICHTE; apud: OEuvres choises de philosophie premiére, Vrin, p.274. 
Um campo transcendental se apresenta como "pura corrente de consciência asubjetiva, consciência pré-reflexiva impessoal, duração qualitativa da consciência sem um eu". ${ }^{160}$ Ao contrário do transcendente, ele não pertence a um sujeito, nem remete a um objeto, mas se define pela imediatez de sua instauração. O empirismo simples remete a elementos sensíveis que, mediados pela consciência, nos devolve às relações de representação e repetição: identidade, semelhança, analogia... É, portanto, necessário partirmos de um empirismo transcendental para falarmos do que se opõe às relações de subjetividade e objetividade.

O que é comprometido, tanto do lado das palavras quanto das coisas, é a relação do nome próprio como intensidade com a multiplicidade que ele apreende instantaneamente. (DELEUZE; Mil Platôs 1; p.53)

"Há qualquer coisa de selvagem e de potente num tal empirismo transcendental". ${ }^{161} \mathrm{O}$ que tratamos no empirismo transcendental é o que se dá entre duas sensações, da passagem de uma à outra como pura intensidade, como variação de potência, portanto, do devir de uma à outra. O campo transcendental, então, mantém uma relação tão somente de direito com a consciência, pois, que, ela não é exprimível senão quando se reflete sobre um sujeito que a remete a um objeto. Mas, no campo transcendental a consciência aparece por toda parte, difusa, com direções e intensidades variáveis e velocidade infinita, subtraindo-se a qualquer revelação. Nestes termos, campo transcendental e puro plano de imanência, se diria um pelo outro.

Quando o sujeito e o objeto, que caem fora do campo de imanência, são tomados como sujeito universal ou objeto qualquer aos quais a imanência é também atribuída, trata-se de toda uma desnaturação do transcendental que não faz mais do que reduplicar o empírico (como em Kant), e de uma deformação da imanência que se encontra, então, contida no

\footnotetext{
160 Ibidem

161 Ibidem
} 
transcendente. [...] Assim como o campo transcendental não se define pela consciência, o plano de imanência não se define por um Sujeito ou um Objeto capazes de o conter. [...] O campo transcendental se define por um plano de imanência, e o plano de imanência, por uma vida. (DELEUZE; $A$ imanência: uma vida...)

"O que é a imanência? uma vida... Ninguém melhor que Dickens narrou o que é uma vida, ao considerar o artigo indefinido como índice do transcendental". ${ }^{162} \mathrm{Na}$ iminência da morte, bem como em sua universalidade, a vida perde $a$ individualidade em troca de uma singularidade; uma hecceidade, não no sentido atribuído por Duns Scotus de individuação, mas de singularização. Uma vida sem subjetivação, onde não há mais possibilidade às referências morais. Essa uma vida está em toda parte e em todos os momentos pelos quais acontecimentos e singularidades se atualizam no sujeito e nos objetos, porém, não tem nela mesma os momentos, mas, um entremomentos, uma continuidade inerente de sua própria condição indefinida, que “apresenta a imensidão do tempo vazio no qual vemos o acontecimento ainda por vir e já ocorrido, no absoluto de uma consciência imediata". ${ }^{163}$ Assim, o que é indefinido, no artigo, é na verdade uma determinação da imanência e não uma indeterminação empírica - a não ser quando determina o que há de singular no individual. Daí, portanto, “o Uno não é o transcendente que pode conter até mesmo a imanência, mas o imanente contido em um campo transcendental. O Uno é sempre o índice de uma multiplicidade". 164

O que é importante no devir-lobo é a posição de massa e, primeiramente, a posição do próprio sujeito em relação à matilha, em relação à multiplicidade-lobo, a maneira de ele aí entrar ou não, a distância a que ele se mantém, a maneira que ele tem de ligar-se ou não à multiplicidade. [...] "Há o deserto. Não teria ainda qualquer sentido dizer que eu estou no deserto. É uma visão panorâmica do deserto. Este deserto não é trágico nem desabitado, ele é deserto só por sua cor,

\footnotetext{
162 ibidem

163 ibidem

164 ibidem
} 
ocre, e sua luz quente e sem sombra. Aí dentro uma multidão fervilhante, enxame de abelhas, confusão de jogadores de futebol ou grupo de tuaregues. Estou na borda desta multidão, na periferia; mas pertenço a ela, a ela estou ligado por uma extremidade de meu corpo, uma mão ou um pé. Sei que essa periferia é o meu único lugar possível, eu morreria se me deixasse levar ao centro da confusão, mas também, certamente, se eu abandonasse a multidão. Não é fácil conservar minha posição; na verdade é muito difícil mantê-la, porque esses seres não param de se mexer, seus movimentos são imprevisíveis e não correspondem a qualquer ritmo. Às vezes eles giram, às vezes vão em direção ao norte, depois, bruscamente, em direção ao leste e nenhum dos indivíduos que compõem a multidão permanece num mesmo lugar em relação aos outros. Consequentemente, encontro-me também permanentemente móvel; tudo isto exige uma grande tensão, mas me dá um sentimento de felicidade violenta, quase vertiginosa". [...] ("nunca mais direi que sou isto ou aquilo"). (DELEUZE; Mil Platôs 1; p.55)

Mas, o que seria essa multiplicidade que unificamos como vida? Acontecimentos, singularidades... virtualidades. Uma vida contém apenas virtuais!

Voltemos a esta história de multiplicidade, porque foi um momento muito importante quando foi criado tal substantivo, precisamente para escapar da oposição abstrata entre o múltiplo e o uno, para escapar da dialética, para chegar a pensar o múltiplo em estado puro, para deixar de fazer dele o fragmento numérico de uma Unidade ou Totalidade perdidas ou, ao contrário, o elemento orgânico de uma unidade ou totalidade por vir - e, sobretudo, para distinguir tipos de multiplicidade. (DELEUZE; Mil Platôs 1; p.59)

Ainda que sejam inseparáveis de atualização, são os acontecimentos ou singularidades que dão ao plano de imanência toda sua virtualidade, bem como, em sentido inverso, a realidade plena dos acontecimentos virtuais advém do plano de imanência. O que o senso comum atribui uma realidade é o processo de atualização de um acontecimento imanente em um estado de coisas e em um estado vivido, do 
qual o plano de imanência se atribui um Sujeito e um Objeto. "Aquilo que chamamos de virtual não é algo ao qual falte realidade, mas que se envolve em um processo de atualização ao seguir o plano que lhe dá sua realidade própria". ${ }^{165}$ Assim, um acontecimento pode permanecer indefinido (não atualizado), em sua virtualidade, tanto quanto, definido, atualizado, sem que nem uma coisa ou outra remeta a uma carência ou falta de realidade.

O plano [de imanência] é como um deserto que os conceitos povoam sem partilhar. O plano não tem outras regiões senão as tribos que o povoam e nele se deslocam. É o plano que assegura o ajuste dos conceitos, com conexões sempre crescentes, e são os conceitos que asseguram o povoamento do plano sobre uma curvatura renovada, sempre variável. (DELEUZE; O que é a filosofia?; p.47)

Ora, o nome próprio não designa um individuo: ao contrário, quando o individuo se abre às multiplicidades que o atravessam de lado a lado, ao fim do mais severo exercício de despersonalização, é que ele adquire seu verdadeiro nome próprio. O nome próprio é a apreensão instantânea de uma multiplicidade. O nome próprio é o sujeito de um puro infinito compreendido como tal num campo de intensidade. (DELEUZE; Mil Platôs 1; p.66)

A guerra vai chegar, os lobos devirão bolcheviques. (DELEUZE; Mil Platôs 1; p.67)

\subsection{Atual e Virtual}

"Toda multiplicidade implica elementos atuais e elementos virtuais. Não há objeto puramente atual". ${ }^{166}$

\footnotetext{
165 ibidem
}

${ }^{166}$ D, p. 173 
“As imagens virtuais não são mais separáveis do objeto atual que este daquelas". ${ }^{167}$ A partir de um tempo pensável, em que o atual se realiza, as imagens virtuais se articulam em torno deste fazendo uma espécie de mensuração, avaliação de um continuum $^{168}$, de um spatium $^{169}$. Por se estabelecerem em um tempo menor que o mínimo do tempo pensável as imagens virtuais são mantidas "sob um princípio de incerteza ou de indeterminação" ${ }^{170}$, como se, desta forma, fossem nuvens de elétrons circundando seu núcleo atômico. Porém, apesar de o atual estar sempre envolvido de virtualidades, não é o atual que define, ou centraliza o processo, mas, um virtual de ordem mais elevada é o que se encontra no centro da nebulosa ${ }^{171}$. $\mathrm{O}$ atual, então, não passa de uma percepção atual, sob o domínio do spatium de um tempo pensável, que está envolvido por virtualidades "que se distribuem por circuitos moventes cada vez mais afastados, cada vez mais largos, que se fazem e se desfazem" ${ }^{172}$... Lembranças! Intercambiando-se, os círculos de imagens virtuais com maior ou menor extensão, correspondem às camadas do objeto atual em maior ou menor profundidade, e, assim, "formam o impulso total do objeto: camadas virtuais, e nas quais o objeto atual tornase, por sua vez, virtual". ${ }^{173}$

O plano de imanência é, assim, formado pelo conjunto de imagem e objeto virtuais, pois é nele que o objeto atual se dissolve. Nele, “o continuum de imagens virtuais é fragmentado, o spatium é recortado segundo decomposições do tempo regulares ou irregulares" ${ }^{174}$, e assim, o impulso total do objeto virtual é quebrado em forças e velocidades correspondentes ao continuum e ao spatium $^{175}$.

\footnotetext{
${ }^{167} \mathrm{D}, \mathrm{p} .174$

168 Idem; Não confundir com continuidade. Continuum é alguma coisa lançada em uma transição gradual, de uma condição única para uma condição diferente, sem nenhuma mudança abrupta.

${ }^{169}$ Ibidem; Espaço no sentido de cavidade, default, gap, intermezzo. Pontos de referência onde podem ser encontradas estruturas importantes.

${ }^{170}$ Ibidem

${ }^{171}$ Ibidem - "cada partícula virtual se envolve de seu cosmos virtual e cada uma, por sua vez, faz o mesmo indefinidamente".

172 D, p. 175

${ }^{173}$ Idem; apud Bergson. Matéria e memória, p. 83-208 (os capítulos II e III analisam a virtualidade da lembrança e sua atualização).

174 Ibidem

175 Plano de imanência: intensidades variáveis, direções múltiplas, velocidade infinita.
} 
O plano se divide, portanto, em uma multiplicidade de planos, conforme cortes do continuum e as divisões do impulso que marcam uma atualização dos virtuais. Mas todos os planos se confundem, conforme a via que leva ao virtual. O plano de imanência compreende, a um só tempo, o virtual e sua atualização, sem que possa haver limite assinalável entre os dois. O atual é o complemento ou o produto, o objeto da atualização, mas esta só tem por sujeito o virtual. A atualização do virtual é a singularidade, enquanto o próprio atual é a individualidade constituída. (DELEUZE; Diálogos; p.176)

Inversamente, quando os círculos se retraem, virtual e atual se aproximam distinguindo-se um do outro cada vez menos. Assim, "uma partícula atual tem seu duplo, no virtual, que se afasta muito pouco dela; a percepção atual tem sua própria lembrança como uma espécie de duplo imediato, consecutivo ou até mesmo simultâneo" 176 . Como no filme Matrix ${ }^{177}$, onde o personagem principal é tragado pelo espelho - "a imagem virtual absorve toda a atualidade do personagem, ao mesmo tempo que o personagem atual não passa de uma virtualidade"178.

$\mathrm{O}$ atual e o virtual coexistem, e entram em um estreito circuito que nos conduz, constantemente, de um ao outro. Já não é uma singularização, e sim uma individuação como processo, o atual e seu virtual. Já não é uma atualização, e sim uma cristalização. A pura virtualidade não precisa se atualizar, já que ela é estritamente correlativa do atual com o qual ela forma o menor circuito. Não há mais inassinalabilidade do atual e do virtual, e sim indiscernibilidade entre os dois termos que se permutam. (DELEUZE; Diálogos; p.179)

Mas, se anteriormente definimos o plano de imanência como o campo onde o objeto atual se dissolve em objeto e imagem virtuais pela expansão de seus círculos, quando esses círculos convergem retraindo-se, e virtual e atual sobrepõe-se, é o tempo que

${ }^{176}$ D, p. 178

${ }^{177}$ The Matrix; propriedade de WARNER BROS CO.

${ }^{178}$ Idem; Deleuze usa essa descrição como exemplo para A dama de Shangai. 
faz o corte fundamental que diferencia o atual do virtual fazendo o presente passar e o passado se conservar.

O tempo pensado, continuum, que define o atual, é o presente, "movimento que se supõe em uma única direção: o presente passa à medida que esse tempo se esgota. Mas o virtual aparece, por seu lado, em um tempo menor do que aquele que mede o mínimo de movimento em direção única"179. O passado se conserva no prolongamento de um tempo menor em outro, virtualmente, em todas as direções. " $\mathrm{O}$ menor tempo que o mínimo de tempo contínuo pensável em uma direção é também o tempo mais longo, mais longo que o máximo de tempo contínuo pensável em todas as direções" $" 180$.

Os dois aspectos do tempo, imagem atual do presente que passa e a imagem virtual do passado que se conserva, se distinguem na atualização, tendo, ao mesmo tempo, um limite inassinalável, mas se permutam na cristalização, até se tornarem indiscerníveis, cada um tomando emprestado o papel do outro. (DELEUZE; Diálogos; p.180)

\footnotetext{
${ }^{179}$ D, p. 179
}

${ }^{180}$ Idem 


\section{Conclusão}

Acreditamos ter demonstrado quanto o ato de estabelecer o novo no mundo é delicado enquanto submetido às amarras da representação. A novação só se efetiva como conhecimento quando rompemos essas amarras e nos colocamos diretamente no fluxo do tempo. É bem verdade que o novo não necessita de nós para se dar, mas se a filosofia sempre buscou a verdade como telos, é pela superação dos obstáculos que nos leva aos falsos conhecimentos que devemos nos pautar. Por isso, optamos em fazer uma genealogia na obra de Deleuze, sem, com isso, almejar a obtenção de uma verdade ou de qualquer certeza sobre o tema, mas como um roteiro para dissolução de nós com os quais nos deparamos cotidianamente em nossa lida com o corpus filosoficum.

O que se apresenta problematizado desde o princípio até a atualidade é a relação interioridade/exterioridade; não à toa que é dela que deriva a representação, e foi também sua crise, crise da representação, que esgarçou a relação entre a Ciência e a Filosofia. Dessa problematização nos deparamos com a questão: o que de fato podemos conhecer, já que os objetos fenomenais nos são inacessíveis em sua essencialidade? A filosofia no final do século XIX se debruçou sobre essa questão orientando suas pesquisas na obtenção de uma percepção imediata, ou seja, sem que a consciência aplicasse sobre ela conteúdos prévios da memória; exatamente aí a crise da representação se precipita. Pois, se a representação opera com conteúdos de 
identidade, semelhança, oposição e analogia, ela prescinde da mediação de mecanismos como reconhecimento, repetição, recognição, comparação sobre algo dado à memória, para realizar seu propósito na obtenção de um conhecimento seguro. E, pela mesma razão, porém com objetivos opostos, os movimentos filosóficos e artísticos que buscaram escapar a esses mecanismos de mediação vêm desenvolver uma Filosofia da Diferença onde, em última análise, são vetores potenciais que dão realidade ao plano de existência fenomênica. A partir desses postulados desenvolvemos a pesquisa em tela e as seguintes conclusões no percurso:

Em Platão, a representação aparece como o registro sensível de um par coexistente: ideia-fenômeno; é algo que guarda a semelhança com a ideia da qual se originou. Porém, essa relação esconde sua verdadeira natureza de fundação. Fundação do imutável que pode a partir daí julgar o pertencimento dos participantes pelo grau de similitude com a ideia. E assim, distinguir os verdadeiros dos falsos pretendentes. Para tanto, o mito é fundamental, pois é ele o centro em que se apoiam os verdadeiros pretendentes. Na dialética platônica a diferença é o produto do método da divisão, e é também sua armadilha, pois quanto maior seu grau de dessemelhança com a ideiamodelo, maior será o grau de liberdade com que ela participará. Daí, a necessidade de uma amarra, uma contenção à diferença, o mito. O mito é então incorporado como elemento que vem estabelecer a diferença, e esta como aquilo que deve ser fundado. Por isso, é a partir do mito que os pretendentes podem ser julgados e sua pretensão medida, para separar com clareza as cópias dos simulacros. As cópias adquirem uma relação íntima, anímica com o modelo, enquanto os simulacros têm uma relação fantasmática com a cópia, uma relação de aparência. Os simulacros, por isso mesmo, adquirem o direito de subverter a filosofia da representação, pois não guardam nenhuma semelhança interior com o modelo, apenas exterioridades. A diferença é seu moto perpétuo, pois o ponto de vista do observador faz parte de sua constituição, atualizando-o sempre como algo novo - devir ilimitado, sempre outro. 
A representação tem sua fundação como doutrina no platonismo, mas se desenvolve sob a influência do cristianismo. Nele a representação não se contenta apenas em fundar, mas agora vai também determinar. Então, como acréscimo ao platonismo, a imagem bem fundada não se apresenta mais como segunda em sua ordem, como no caso da cópia em relação à ideia que lhe dava fundamento, agora, como essência ideal, a diferença é a qualidade que o fundamento possui em segundo lugar na condição de semelhança, e, assim, a imagem bem fundada se denominará representação. Dessa forma, a representação adquire novo status, pois deixou de ter uma relação de similitude com o fundamento passando a ter o próprio fundamento como interioridade, e a semelhança como sua exterioridade. O modelo, assim, continua monocentrado, se antes tinha o fundamento como limite, agora pode alcançar o ilimitado como essência ideal e mantê-la como centro. Porém, ainda aqui, o simulacro é o signo que vem produzir uma ressonância interna que rompe esse modelo representacional formando séries heterogêneas, ou seja, acentradas, de elementos díspares.

O simulacro rompe qualquer relação ideal ou essencial, portanto nega tanto o original quanto a cópia. Ele retira sua identidade da série que ele mesmo cria, fazendo com que essa identidade se perca, enquanto se atualiza, ao retornar a si mesma. Portanto, divergente e diferenciante. Essa é a potência do fantasma: uma criação ininterrupta. E é exatamente neste ponto que a leitura que Deleuze faz do conceito nietzscheano de eterno retorno se adéqua ao de simulacro.

A filosofia da diferença não se coaduna às perspectivas de uma representação infinita, pois, nesta última, a diferença se apresenta como a negação do Ser. Mas, na filosofia da diferença o Ser é o próprio processo de diferenciação. O modelo dialético de representação infinita cai no movimento, onde o que é negado é a diferença do que se conserva na memória, num círculo de repetições do mesmo. $\mathrm{O}$ eterno retorno, ao contrário, é a consequência da negação como afirmação da diferença. $O$ eterno retorno apresenta, assim como o platonismo, dois conteúdos: o manifesto que se 
adequaria a representação, pois, centrado, retornaria sempre ao mesmo (ideia ou essência); e o latente, em que o que retorna no eterno retorno são as séries divergentes. Nesta última acepção o eterno retorno é o Ser do simulacro, pois ao retornar, retorna ao diferente. Mas, ainda, temos com o eterno retorno seu par conceitual, a vontade de potência. Esta é para Nietzsche o elemento genealógico da força, isso significa que em um campo de forças (uma força nunca encontra-se isolada), a vontade de potência vai determinar tanto a diferença de quantidade entre as forças, quanto a qualidade delas. No primeiro caso, se são dominantes ou dominadas, e no segundo se são ativas ou reativas. Como essas relações referem-se às qualidades primordiais das forças e na vontade de potência essas qualidades primordiais são de afirmação e negação, é a afirmação que vai dotar a força de um poder ativo e, consequentemente, a negação vai dotá-la de um poder reativo. Dessa forma, a vontade de potência é propriamente o devir ativo e o devir reativo contido nas forças. É preciso ainda salientar que o poder ativo e o reativo se estabelecem na relação das qualidades entre as forças contidas em um campo de forças, não se mantendo para além de sua própria condição e assim em um campo de forças uma força será ativa em determinada situação e simultaneamente, reativa em outra, ou, ainda, no caso quantitativo, dominante em relação a umas e dominada em relação a outras; encontrando-se em um eterno conflito à ação de uma sobre a outra pode mudar sua condição de ativa à reativa, ou dominante à dominada. Por isso, Deleuze defende a primazia do conteúdo latente do eterno retorno, pois apenas ele dá a condição para resguardar o sentido de uma vontade afirmativa, fazendo do eterno retorno o elemento de novação.

Daí foi preciso seguir à crítica que Deleuze faz à estrutura conceitual da Filosofia, que se desenvolve a partir de um universo cognitivo pré-filosófico em que sua gênese se dá no senso comum. Os enunciados filosóficos têm duplo caráter: enunciados objetivos que se apresentam como formas conceituais; e enunciados subjetivos, que submetem a conceituação a um sentimento oriundo de uma vivência. Recorremos a Bergson, assim como Deleuze o faz, para demonstrarmos que, se um conceito vem exprimir uma ideia que se deu por uma intuição, é necessário fabricá-lo em sua 
singularidade e não como um objeto universal. Pois, o insight no qual ela nasce é instantaneamente único, porém múltiplo em potencialidades; e, assim, essa ideia só poderá ser conceituada se aprisionada em elementos que a generalizam e a abstraem. Dessa forma, imaginamos criar uma identidade conceitual àquela ideia, mas de fato demos, através de referências universais, uma pretensão conceitual filosófica a elementos do senso comum. Este modelo nos possibilita o reconhecimento de uma forma ideal que nos coloca em uma zona de conforto, mas retira da ideia original o que ela detinha de radical: seu componente diferencial que fazia dela um novo. É aqui que a crítica deleuzeana aos quatro estágios da representação torna-se mais contundente, pois enquanto o pensamento reconhecer seu duplo, o mesmo, na memória, não conseguirá escapar às amarras da representação (a identidade no conceito, a oposição no predicado, a analogia no juízo, a semelhança na percepção), mas o ato de pensar necessita de uma violência que o force a sair dessa zona de conforto.

O "tempo fora dos gonzos..." 181 , figura como a primeira abordagem que Deleuze faz do que ele intitulou de "reversão kantiana", que é a introdução do tempo como agente diferencial, e, portanto, descentralizador. O tempo deixa de ser visto como cíclico assujeitado aos movimentos do mundo para se tornar aquilo que propicia o movimento, ou seja, a forma imutável da mudança e do movimento. Essa superação se dá no campo objetivo, na exterioridade do tempo, pois o tempo, assim como o espaço, a partir de Kant são as formas a priori da sensibilidade, e, portanto, toda representação só pode se dar no espaço e no tempo. Mas, temos ainda a questão da interioridade do tempo, o movimento intensivo da alma. E, se Descartes é quem laiciza essa ideia, é Kant que problematiza o surgimento do duplo "Eu" no cogito cartesiano. Pois, se no ato de pensar eu me reconheço como aquele que pensa, o pensar é uma determinação em si mesma. É uma produção intensiva que se determina no tempo e que vai buscar em seu duplo uma produção extensiva que se determina no espaço. A representação desse segundo $E u$, existente, pelo primeiro $\mathrm{Eu}$, consciente,

${ }^{181}$ Shakespeare, Hamlet, 1, 5 
não pode assumir a forma do mesmo - a forma do reconhecível - pois, que diferem um do outro em suas determinações originais (extensiva, intensiva), assumindo, assim, a forma do outro - a forma do divergente. Como aquilo que se diferencia em sua exterioridade está submetido ao tempo, a dupla vertente do Eu está duplamente submetida ao regime do tempo, tanto em sua interioridade quanto em sua exterioridade. Portanto, é o tempo e somente nele que a ligação entre o consciente e o existente pode se consolidar. Deleuze atribui a terceira reversão ao modelo moral de Kant, onde o Bem fica submetido à Lei. E esta última impõe à consciência uma renuncia tão rigorosa que coloca até mesmo a existência sob sua exigência. É o tempo que segue inexorável submetendo o limite da nossa exterioridade a uma interioridade ilimitada. Consolidando a reversão kantiana, a imaginação apresenta um poder de reflexão livre sobre os fenômenos, que faz dela a faculdade capaz de conferir ao tempo uma potência conceitual infinita. A determinabilidade do duplo Eu no tempo e sua correspondência na divisão exterior/interior é substituída por uma interação indeterminada onde o tempo é emancipado por um pathos, como aquilo que se diferencia nele mesmo. O tempo é concebido por Deleuze, a partir da reversão kantiana, como o plano diferencial onde as faculdades do entendimento entram em polémos, levando-as a seus limites e forçando-as a ultrapassá-lo como as forças ativa e reativa que são. Apenas nessa forma, na forma do tempo patológico, conseguimos encontrar a violência necessária à saída das amarras da representação.

A questão que se apresenta agora é como estabelecer uma via de acesso a um conjunto de informações indeterminadas em um fluxo de tempo ilimitado sem mediálas através de uma determinação ou limite, e sem recorrer novamente ao senso comum. A raiz dessa questão está na distinção da natureza dos problemas e não na graduação destes, e como nos ensina Bergson, a quem Deleuze retorna, uma filosofia da diferença tem como primeira tarefa determinar as diferenças de natureza entre as coisas para voltar às próprias coisas como elas mesmas (in,p.50). O que Bergson propõe é um método que seja capaz de "esculpir" um conceito que seja exclusivo ao objeto, que apresente dele não sua interioridade ou exterioridade, mas sua própria diferença interna. A esse método Bergson chamou de intuição. E sua aplicação 
considera três etapas: denunciar os falsos problemas; reencontrar as verdadeiras articulações do real; e, resolver os problemas mais em função do tempo que do espaço. Os falsos problemas aparecem de uma confusão em seus termos e, portanto, são inexistentes ou são problemas mal colocados, provenientes de mistos mal analisados. Todo conhecimento empírico se dá através de mistos, nossa percepção sensível está sempre impregnada de elementos misturados, como por exemplo, nossa relação espacio-temporal, e os tratamos como se compreendessem uma unidade. Reencontrar as verdadeiras articulações do real trata-se de dividir o misto por suas diferenças de natureza, assim, no caso do espaço e do tempo, nas duas presenças puras: da extensão e da duração. Por fim, colocar o problema mais em função do tempo que do espaço traz o sentido fundamental que Bergson dá a seu método. A duração carrega em si mesma uma heterogeneidade qualitativa - as diferenças de natureza; enquanto que a extensão, uma homogeneidade quantitativa - as diferenças de grau. Porquanto as diferenças de natureza encontram-se em si e por si, as diferenças de grau encontram-se fora de si e para nós. Assim, chegamos à confusão natural que se instala no senso comum: a duração é o que traz a diferença em si mesma, portanto sua condição original é se diferenciar, tornar-se outro; e a matéria como produto da extensão é o que se repete, mantém-se o mesmo. O curioso é que se tratadas como tendências, a estabilidade contida na repetição vincula sua permanência ao modelo da representação (identidade, semelhança, oposição e analogia) que poderíamos chamar de uma efemeridade conceitual; já ao contrário, o movimento de diferenciação faz dele em si mesmo a própria coisa, uma coisa que permanece. E é assim que o conceito torna-se a coisa; como tendência, ele é a própria diferença interna. Bergson vai ainda comparar a diferença interna a vida; a vida como processo da diferença; a vida como elemento de novação.

Uma vida é uma pura imanência, pois ela não tem uma existência exterior a ela mesma. Uma vida não pertence a um sujeito, mas o contrário seria uma afirmação verdadeira. É uma potência completa. Na imanência, uma vida se diz pelo artigo indefinido, por isso, o homem dos lobos perde sua identidade para alcançar um nome próprio; perde a individualidade para se constituir em uma singularidade - uma 
ecceidade: uma vida de acontecimentos e singularidades em uma continuidade inerente a sua condição indefinida. A imanência é então o todo contínuo de uma multiplicidade contida no campo transcendental. Um campo transcendental é essa multiplicidade em uma consciência pré-reflexiva, a-subjetiva, que está em toda parte, porém difusa; ela só é exprimível quando se reflete em um sujeito que a remete a um objeto. O homem dos lobos não é um lobo, ele adquire seu nome da reflexão da multiplicidade lobo, que vai promover nele um devir lobo. O campo transcendental e o puro plano de imanência são o mesmo. E essa multiplicidade de acontecimentos dá ao plano de imanência sua virtualidade.

Agora virtual e atual são a forma do real e de sua mútua interação vamos retirar as articulações do tempo. O atual se realiza a partir de um tempo pensável, já as imagens virtuais se dão em um tempo menor que o tempo pensável. Por isso o atual está sempre envolto de virtualidades, mas nem por isso vem dele a realidade do modelo, pois o atual é o limite onde o plano se atualiza. Em sendo o atual aquilo que se presentifica ele não passa de uma percepção atual. O virtual com seu movimento acentrado em um tempo menor que o tempo pensável vai alargando e afastando seus círculos de imagens virtuais que vão corresponder às camadas do objeto atual que acaba por torná-lo virtual em um movimento de singularização. De outro modo, quando os círculos se contraem, virtual e atual vão se tornando um misto indiviso, o plano já não se atualiza, pois o movimento agora é de individuação e o resultado é uma cristalização que os torna indiscerníveis cada um assumindo o papel do outro.

Através do plano de imanência e da relação entre atual e virtual, Deleuze dá consistência de realidade às articulações do tempo como substrato da diferença, estabelecendo um acordo com seus parceiros conceituais, de Platão à Bergson, acordo com o qual pode sustentar a ruptura com o modelo representacional, em defesa desse campo de tensões diferenciais gerador do novo. 


\section{Referências bibliográficas}

BERGSON, H. Matéria e Memória; São Paulo: Martins Fontes, 2006.

. A Evolução Criadora; São Paulo: Martins Fontes, 2005.

. Duração e Simultaneidade; São Paulo: Martins Fontes, 2006.

. O Pensamento e o Movente; São Paulo: Martins Fontes, 2006.

BORGES, J. Nova Refutação do Tempo, Obras Completas, II; São Paulo:

Globo, 1999.

DELEUZE, G. A Dobra - Leibniz e o Barroco; Campinas: Papirus, 2011.

. A Filosofia Crítica de Kant; Lisboa: Edições 70, 2012.

. A Ilha Deserta; São Paulo: Iluminuras, 2014.

. Bergsonismo; São Paulo: Editora 34, 1999.

. Cinema 1 - A Imagem Movimento; São Paulo: Brasiliense, 1985.

. Cinema 2 - A Imagem Tempo; São Paulo: Brasiliense, 2011.

. Conversações; São Paulo: Editora 34, 2013.

. Crítica e Clínica; São Paulo: Editora 34, 2013.

. Diferença e repetição; São Paulo: Graal, 2009.

. Empirismo e Subjetividade; São Paulo: Editora 34, 2012.

. Francis Bacon - Lógica da Sensação; Rio de Janeiro: Zahar, 2007.

. Lógica do Sentido; São Paulo: Perspectiva, 2011.

. Nietzsche e a Filosofia; Rio de Janeiro: Editora Rio, 1976.

DELEUZE, G. e GUATTARI, F. Mil Platôs I; São Paulo: Editora 34, 2011.

. O que é a Filosofia?; São Paulo: Editora 34, 2010.

DELEUZE, G. e PARNET, C. Diálogos; São Paulo: Escuta, 1998.

DERRIDA, J. Espectros de Marx; Rio de Janeiro: Relume Dumará, 1994.

DESCARTES, R. Coleção Os Pensadores; São Paulo; Nova Cultural, 2004. . Meditações sobre Filosofia Primeira; Campinas: Unicamp, 2008.

FOUCAULT, M. As Palavras e as Coisas; São Paulo: Martins Fontes, 2007.

HEGEL, F. Coleção Os Pensadores; São Paulo; Nova Cultural, 2004.

. Enciclopédia das ciências filosóficas em epítone; Lisboa: Edições 70, 1969. 
HUME, D. Tratado da Natureza Humana; São Paulo: UNESP, 2009.

KANT, I. Coleção Os Pensadores; São Paulo; Nova Cultural, 2005.

Crítica da Razão Pura; São Paulo: Ícone Editora, 2007.

MACHADO, R. Deleuze - A Arte e a filosofia; São Paulo: Zahar, 2013.

MERLEAU-PONTY, M. A Fenomenologia da Percepção; São Paulo: Martins Fontes, 2006. . O Olho e o Espírito; São Paulo: Cosac Naify, 2013.

NIETZSCHE, F. A Gaia Ciência; São Paulo: Hemus, 1981. . Além do Bem e do Mal; São Paulo: Hemus, 1976. . Assim Falou Zaratustra; Rio de Janeiro: Civilização Brasileira, 2006. . Aurora; São Paulo: Companhia das Letras, 2008. . Crepúsculo dos Ídolos; São Paulo: Companhia das Letras, 2010. . Genealogia da Moral; São Paulo: Companhia das Letras, 2008. . Humano, demasiado humano; São Paulo: Schwarcz, 2008. . Humano, demasiado humano II; São Paulo: Companhia das Letras, 2008.

PELBART, P. O Tempo Não-Reconciliado; São Paulo: Perspectiva, 2015.

PRIGOGINE, I. O Fim das Certezas; São Paulo: Unesp, 1996.

RICOEUR, P. O Si-Mesmo como Outro; São Paulo: wmf Martins Fontes, 2014.

ROMEYER-DHERBEY, G. Os Sofistas; Lisboa: Edições 70, 1986.

ZOURABICHVILI, F. O Vocabulário de Deleuze; Rio de Janeiro, 2004: Versão Eletrônica - IFCH Unicamp - Centro Interdisciplinar de Estudos em Novas Tecnologias e Informação. 